\title{
New Geochemical and Mineralogical Data on Rocks and Ores of the NE Flank of the Oktyabr'skoe Deposit (Norilsk Area) and a View on Their Origin
}

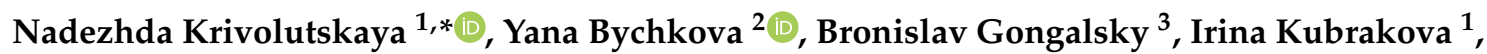 \\ Oksana Tyutyunnik ${ }^{1}{ }^{\oplus}$, Elena Dekunova ${ }^{2}$ and Vladimir Taskaev ${ }^{3}$ \\ 1 Vernadsky Institute of Geochemistry and Analytical Chemistry, Russian Academy of Sciences, \\ 119991 Moscow, Russia; kubrakova@geokhi.ru (I.K.); toa-6767@mail.ru (O.T.) \\ 2 Geological Department, Lomonosov Moscow State University, 119463 Moscow, Russia; \\ andrewbychkov@rambler.ru (Y.B.); 1.dekunova@ya.ru (E.D.) \\ 3 Institute of Ore Deposits, Petrography, Mineralogy and Geochemistry, Russian Academy of Sciences, \\ 119109 Moscow, Russia; brgon@mail.ru (B.G.); ttvtest@yandex.ru (V.T.) \\ * Correspondence: nakriv@mail.ru; Tel.: +7-926-543-4787
}

\section{check for}

updates

Citation: Krivolutskaya, N.; Bychkova, Y.; Gongalsky, B.; Kubrakova, I.; Tyutyunnik, O.; Dekunova, E.; Taskaev, V. New Geochemical and Mineralogical Data on Rocks and Ores of the NE Flank of the Oktyabr'skoe Deposit (Norilsk Area) and a View on Their Origin. Minerals 2021, 11, 44. https:// doi.org/10.3390/min11010044

Received: 24 October 2020 Accepted: 28 December 2020 Published: 31 December 2020

Publisher's Note: MDPI stays neutral with regard to jurisdictional clai$\mathrm{ms}$ in published maps and institutional affiliations.

Copyright: (C) 2020 by the authors. Licensee MDPI, Basel, Switzerland. This article is an open access article distributed under the terms and conditions of the Creative Commons Attribution (CC BY) license (https:// creativecommons.org/licenses/by/ $4.0 /)$.

\begin{abstract}
The Oktyabr'skoe deposit in the Norilsk ore district is the largest platinum-copper-nickel deposit in the world. It contains a huge main orebody $\left(2.4 \mathrm{~km}^{3}\right)$ of massive sulfide ores and some smaller sulfide bodies. Almost all publications on this deposit are devoted to the main orebody. However, to solve the problems of the deposit genesis, it is necessary to take into account the geological structure of the entire area and the composition of all orebodies. For the first time we present data on the inner structure, geochemical and mineralogical characteristics of the intrusive body, and related the disseminated and massive sulfide ores (orebody number C-5) in the northeastern flank of the deposit. The intrusion studied in the core of the borehole RG-2 consists of several horizons including the following rock varieties (from bottom to top): olivine gabbro-dolerites, taxitic gabbro-dolerites, picritic gabbro-dolerites, troctolites, olivine-free gabbro-dolerites, ferrogabbro, and leucogabbro. The intrusion shows a strong differentiated inner structure where high-Mg rocks (up to $25 \mathrm{wt} . \% \mathrm{MgO}$ troctolites and picritic gabbro-dolerites) in the bottom are associated with low-Mg rocks (6-7 wt.\%, gabbro-dolerites, leucogabbro, ferrogabbro) without intermediate differentiated members (8-12 wt.\% MgO olivine gabbro-dolerites). Rocks are characterized by low $\mathrm{TiO}_{2}$ content ( $\leq 1 \mathrm{wt.} \%$ ). Taxitic gabbro-dolerites, picritic gabbro-dolerites, and troctolites contain disseminated sulfide chalcopyrite-pyrrhotite mineralization (32 $\mathrm{m}$ thick). $\mathrm{Cu}$ and Ni concentrations reach up 0.74 and $0.77 \mathrm{wt} . \%$, respectively. Massive ores $(27 \mathrm{~m})$ occur in the bottom part of the intrusion. The ores consist of pentlandite, chalcopyrite and pyrrhotite, the latter mineral dominates. Their chemical composition is stable: $\mathrm{Cu} / \mathrm{Ni} \sim 1, \mathrm{Pd} / \mathrm{Pt}$ varies from 5 to 6 . The $\mathrm{C}-5$ orebody is similar to the $\mathrm{C}-3$ orebody in terms of mineral and chemical compositions, and differ from the nearby the C-4 orebody which is characterized by a $\mathrm{Cu} / \mathrm{Ni}$ ratio changing from 5 to 8 . On the basis of geochemical and mineralogical data, it is assumed that orebodies C-3 and C-5 are associated with one intrusion, while the orebody number C-4 is related to another intrusive body. Thus, the deposit has a more complex structure and includes several more intrusions than is usually considered.
\end{abstract}

Keywords: copper-nickel ore; mafic intrusions; Norilsk district; Oktyabr'skoe deposit

\section{Introduction}

The NW Siberian flood basalts province contains numerous ultrabasic-basic intrusions with platinum group elements (PGE)-Cu-Ni mineralization [1-4]. This territory is the world's largest PGE-Ni metallogenic province, comprising deposits of the Norilsk and Talnakh ore junctions. The three unique deposits Oktyabr'skoe, Talnakh, and Norilsk 1 [5-8] comprise a world-class resource of nickel (15.3 Mt) and platinum group elements 
(8300 t) concentrated in sulfide ores [9]. The Oktyabr'skoe deposit is the largest known deposit in the Norilsk district, which has been of interest to geologists due to the extent of its sulfide orebodies and its mineralogical diversity. Many new minerals were discovered in the main orebody, such as talnakhite, pollyarite, sobolevskite, among others [10-15]. Genkin and co-authors summarized the mineralogical data in 1981 [16]. The deposit morphology, its location in stratigraphic sequence, disturbance due to faults, and ore composition have already been studied in detail [17-25] but its northeastern part has not been described. The Talnakh and Oktyabrsk'oe deposits were initially thought to be genetically related to a single intrusive body (the Talnakh intrusion) consisting of the northeastern, southwestern, and northwestern branches [8,26]. Further studies related these deposits to two separate massifs: Talnakh and Kharaelakh $[17,18]$ formed from different magmas intruded at different stratigraphic levels, i.e., Carboniferous-Permian and Devonian deposits, respectively. It was demonstrated, in [27], that the Talnakh intrusion consists of two discrete intrusive bodies, instead of two branches. The structure of the Oktyabr'skoe deposit is more complex than that of Talnakh. However, with the exception of the Main orebody of the Oktyabr'skoe deposit, the other smaller massive ore bodies forming the deposit part are poorly studied.

In order to refine our understanding of origin of the Oktyabr'skoe deposit, the magmatic structure of the area requires investigation. Previous workers, despite little evidence, speculated that the deposit was formed by multiple magmatic events [28,29]. However, they did not publish geochemical and mineralogical data on individual orebodies that could confirm their relation to different intrusions. We began the study of separate orebodies and related intrusive rocks, which could give new information on their geochemical and mineralogical composition and whole intrusive structure of the deposit. The latest drilling data in 2017-2018 by Norilskgeology Ltd. strongly support the idea of the complex intrusive structure of the Oktyabr'skoe deposit, where different mineralogical and geochemical composition orebodies are related to several intrusions. We present new data on the C-5 orebody, which has a composition similar to the C-3 orebody. They are both represented by tetragonal chalcopyrite-pyrrhotite assemblages, while the C-4 orebody, located in close vicinity, consists of $\mathrm{Cu}$ minerals with $\mathrm{S}$ deficits in mineral structure (talnakhite) and must be formed under other physics-chemical conditions. This is the first attempt to demonstrate the complex structure of the NE flank of the Oktyabr'skoe deposit, revealing its complicated formation history.

\section{Geology of the Norilsk District and the Oktyabr'skoe Deposit}

The Norilsk ore district is located near the Arctic circle, at the right bank of the Yenisey river (Figure 1). Tectonically, it is located within the Norilsk-Igarka paleorift zone, consisting of the Kharaelakh, Norilsk, and Iken troughs. The eastern boundary of the Norilsk district coincides with the western part of the Tunguska syneclise (Figure 1), located at the Siberian platform. This area includes Cambrian-Permian terrigenous-sedimentary rocks and overlapping volcanogenic rocks of the Siberian trap province [30,31]. The terrigenous-sedimentary rocks are exposed in the cores of anticlines structures, e.g., the Dudinsky and Khantaysko-Rybninsky swells. The core of the synclines have been filled by effusive rocks. The maximum thickness of tuff-lava sequence reaches $3.4 \mathrm{~km}$. Volcanic rocks can be subdivided into 11 formations. Their composition varies from high Ti concentrations (3.8 wt.\%) at the base to low Ti concentrations at the top (1-1.5 wt.\%) [5,32-34].

Numerous mafic intrusive bodies, also referred to the Traps formation [35], are mainly localized in sedimentary rocks, under volcanogenic deposits or in the lowest formations (Ivakinsky-Nadezhdinsky). They form sill-like and dike-like bodies. These intrusions have been divided into a number of intrusive complexes [30], of which the most important is the Norilsk complex, composed of differentiated intrusions. All deposits in the Norilsk region are generally related genetically to the Norilsk intrusive complex (Oktyabr'skoe, Talnakh, Norilsk 1, Maslovsky, Norilsk 2, Pyasino-Vologochansky, etc.) [17]. The Kharaelakh and Talnakh intrusions are localized in the southern part of the Kharaelakh trough (Figure 2) and 
form the Talnakh ore junction. The intrusions are located near the Norilsk-Kharaelakh Fault (NKF), which is considered as the main magma conduit for ore-bearing intrusions [17].

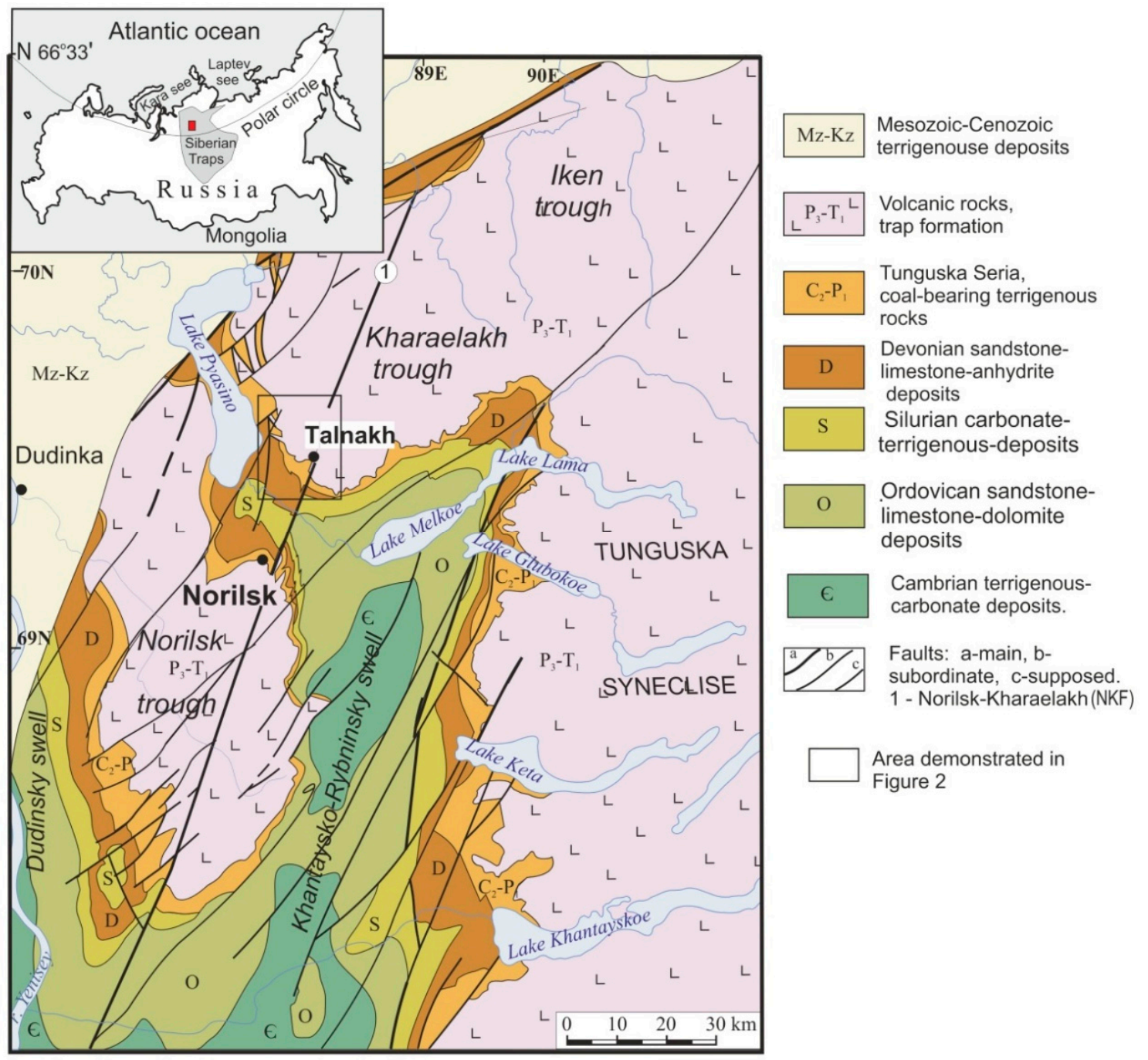

Figure 1. Schematic geological map of the Norilsk district (constructed by the authors based on [36]) with its position in Russia (red square) in inset.

The Kharaelakh and Talnakh intrusions are situated at different stratigraphical levels: the Talnakh intrusion mainly occurs in the coal-bearing terrigenous rocks of the Tunguska series to the East of the NKF, whereas the Kharaelakh body is hosted by the Devonian terrigenous-carbonates located west of the NKF (Figure 2). The Oktyabr'skoe deposit is associated with the Kharaelakh intrusion [37]. This area also includes other massive sulfide orebodies. The largest body is called the "Main orebody" (Kh-O, Figure 3), it is found in the western part of the Oktyabr'skoe deposit area. It is related to the largest Kharaelakh intrusion, which splits into a series of apophyses in the west [27]. Several other smaller orebodies are located in central and eastern parts of the Oktyabr'skoe deposit's area (Figure 3). However, these orebodies are not associated with the same large intrusion as the main orebody, but instead of it they are related to a series of subordinate intrusive bodies. They are all emplaced in the Lower Devonian rocks along the contact between the Kurejsky and Razvedochninsky Formations (Figure 2). The sedimentary deposits in this area are mainly represented by carbonate-terrigenous rocks including marls, dolomites and mudstones with limestone layers. In contrast to underlying Zubovsky and overlying Manturovsky and other formations, evaporites are almost absent in surrounding rocks 
of the Kharaelakh intrusion. The massive sulfide lenses of C-5 and C-6 have a length of several hundred meters and thickness $30 \mathrm{~m}$ compared to $150 \mathrm{~m}$ thickness of enclosing intrusive bodies.

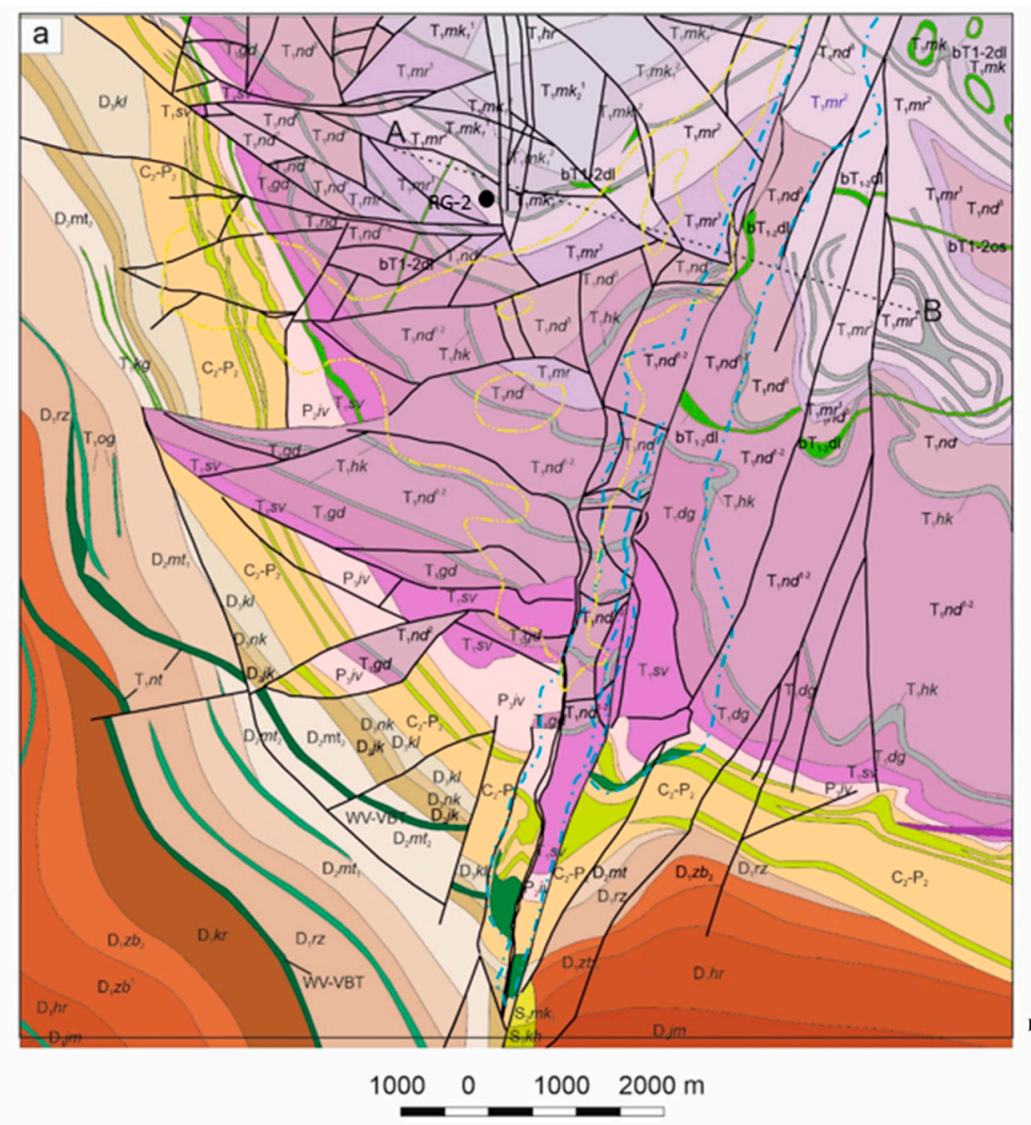

Cross section A-B Scale 1:10 000

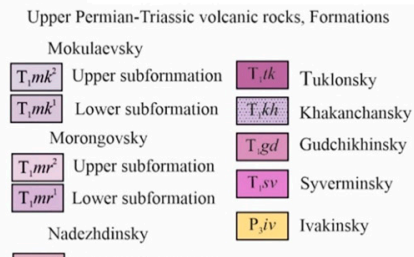

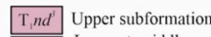

$\mathrm{T} n d^{2} \begin{aligned} & \text { Lower + middle } \\ & \text { subformation }\end{aligned}$

Intrusive rocks, Complexes

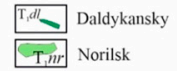

$\widehat{T, n t}$ Lower Talnakh

\begin{tabular}{|lll}
\hline $\mathrm{T}, \mathrm{og}$ & Ogonersky \\
\hline
\end{tabular} P,er Ergalakhsky

\section{a 6/ Faults: a) main} $\square$ Massive ore
Sedimentary rocks Middle Carboniferous- Middle Permian C,-P. Tunguska Seria Coal-bearing Devonian Formations

D.jk-kl Juktinsky-

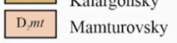

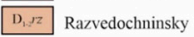

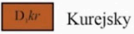

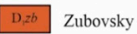

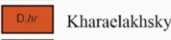
Jampakhsky Contours of intrusions projections Silurian deposits on the surface $\mathrm{S}$ Undivided Kharaelakh $\quad$ RG-2 Borehole

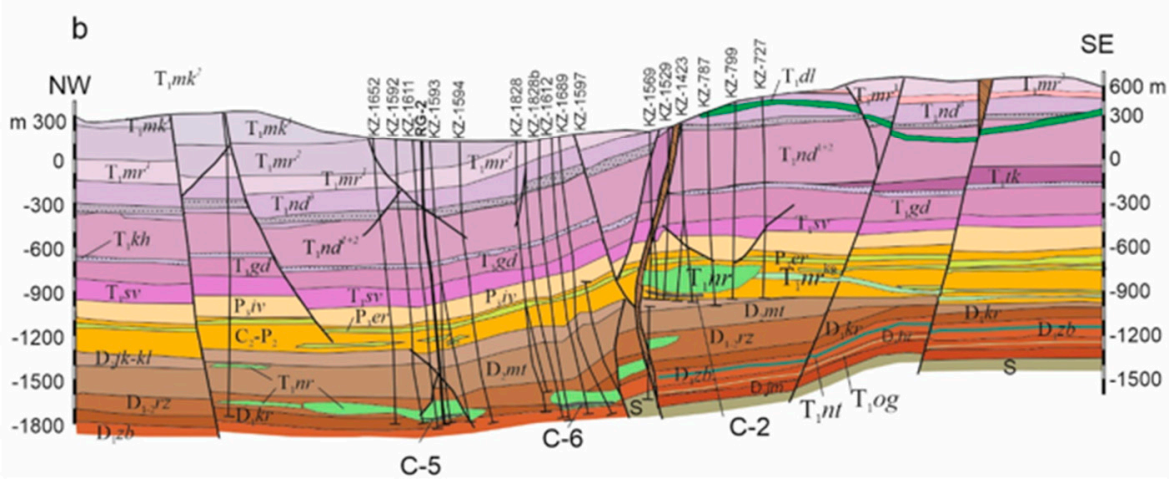

Figure 2. Geological map of the Talnakh ore junction (a) and sublatitude cross-section (b) (after Norilskgeology Ltd. data with additional corrections from the authors). 


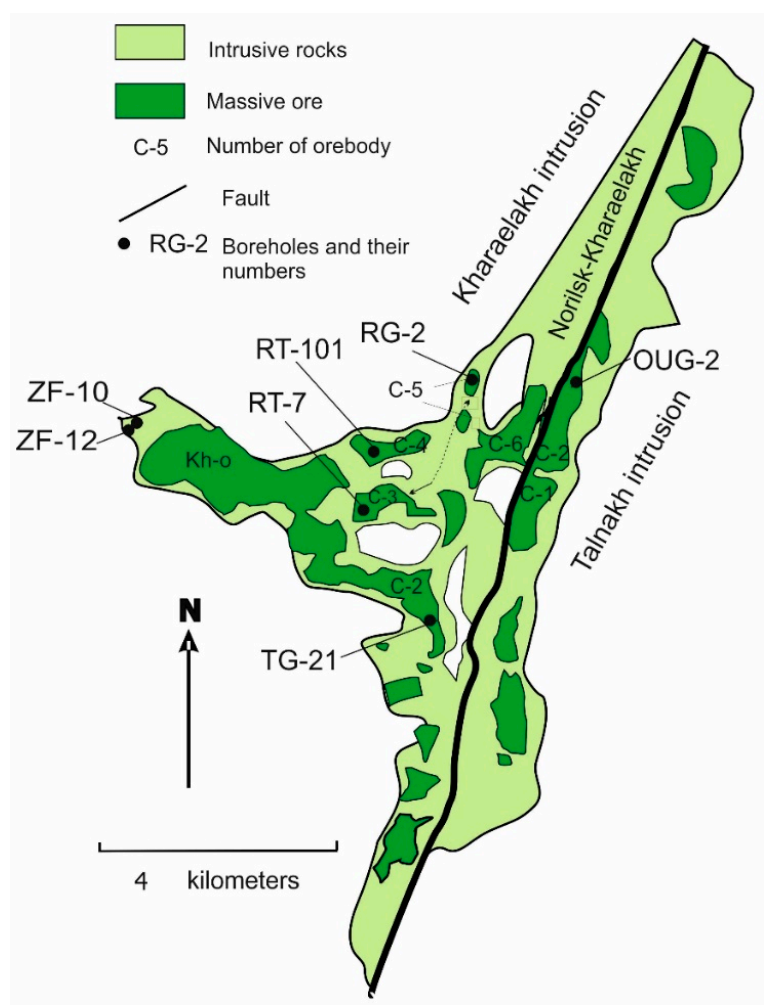

Figure 3. Projection of intrusive rocks and massive orebodies on the horizontal plane (according to blue and green contours in Figure 2) (after Norilskgeology Ltd. data, with changes).

\section{Materials and Methods}

The authors studied the intrusive rocks and ores in northeastern flank of the Oktyabr'skoe deposit (Figure 3). The most representative core, borehole RG-2 penetrating the orebody C-5, was studied in detail such that, samples were taken from both silicate host rocks as massive sulfide ore (Figures 2 and 3) (drill cores from the other boreholes of this area shown in Figure $2 \mathrm{~b}$ are not available). These data were compared with the data reported in previous studies.

The collected samples were analyzed at the Institute of Geology of Ore Deposits, Petrography, Mineralogy, and Geochemistry (IGEM), Russian Academy of Sciences (analyst A.I. Yakushev). The major elements concentrations were determined using an XRay Fluorescence spectrometer on the vacuum sustained action (dispersion of wavelength), model AxiosmAX production company PANalytical (the Netherlands, 2012; www.panalytical.com). The spectrometer is equipped with an X-Ray tube with a capacity of $4 \mathrm{~kW}$ and an $\mathrm{Rh}$-anode. The maximum rated tube voltage is $60 \mathrm{kV}$ and max anode current is $160 \mathrm{~mA}$. Quality control measurements were performed on the U.S. Geological survey (USGS) standard rocks [38].

Trace elements were analyzed using inductively coupled plasma mass spectrometry (ICP-MS) on a X-Series II ICP mass spectrometer at Lomonosov State University (analysts Ya. Bychkova and E. Dekunova). To this end, the prepared samples were decomposed by acids, and an indium solution was then added as an internal standard. Its sensitivity throughout the whole mass scale was calibrated against standard 68-element solutions (ICP-MS-68A, HPS, and solutions A and B). Analysis of samples and the standard (BHVO-2, COQ-1) was alternated at a frequency of 1:10 for quality and accounts for the sensitivity drift. The detection limits of elements were obtained in the range of $0.1 \mathrm{ppm}$ for elements with heavy and intermediate atomic weights to $1 \mathrm{ppm}$ for light elements. The accuracy of the analyses was $1-3 \%$. The elemental concentrations were calculated using a series of standard solutions such as ICP-MS-68A and HPS (A and B) within the concentration range of $0.03-10 \mathrm{ppb}$. 
Base and precious metals were analyzed in samples $(0.5 \mathrm{~g})$ that were decomposed with nitric and hydrochloric acids, followed by fusion of the residue with sodium peroxide. Major elemental components (Al, As, Ba, Be, Cd, Cr, Co, Cu, Mg, Fe, Ni, P, S, Ti Pb, Sr, Zn) were determined by ICP-AES (Iris Intrepid II XDL, Thermo Elemental Corp.); whereas $\mathrm{Se}, \mathrm{Te}$ and Ag were measured by ETAAS (simultaneous multielement atomic absorption determination of arsenic, antimony and bismuth, SOLAAR MQZ, Thermo Electron Corp., Waltham, MA, USA). The ICP-MS-68 solution, parts A and B (High-Purity Standards, USA), were used for calibration. PGE and Au were determined after ion-exchange separation of matrix components on the column of AG-X8 cation exchange resin (the preconcentration technique is described in detail in [39]). The ISP-AS (Iris Intrepid II XDL, Thermo Elemental Corp. USA) was applied to measure Pd, Pt, Ir, Ru and Rh, ICP whereas ETAAS (AA7000, Shimadzu) was used for Au. Along with our samples, SRM VT-1 (copper-nickel sulfide ore) (Russia) was analyzed as an external standard.

Minerals compositions were determined using a JEOL JXA 8200 SuperProbe at IGEM RAS (analyst V.I. Taskaev) at $40 \mathrm{nA}$ beam current and $20 \mathrm{kV}$ accelerating voltage; the counting times were $10 \mathrm{~s}$ when major components were analyzed and $20 \mathrm{~s}$ for trace elements.

\section{Results}

\subsection{Petrographic Characteristics of the Rocks}

Figure $4 \mathrm{a}$ demonstrates the structure of the intrusive body penetrated by the borehole RG-2. This intrusion is $130 \mathrm{~m}$ thick, including a massive sulfide ore $(27 \mathrm{~m})$. This intrusive body consists of the following horizons (from bottom to top): contact gabbro-dolerites, olivine gabbro-dolerites, taxitic gabbro-dolerites, troctolites, and picritic gabbro-dolerites overlapped by ferrogabbros and leucogabbros. Here, we use the classification of Norilsk geologists $[17,18,26,28,29]$. This section is characterized by a contrasting and differentiated structure, in which high-magnesium rocks account for a significant volume in the lower part of the intrusion and the upper part consists of low-magnesium rocks.
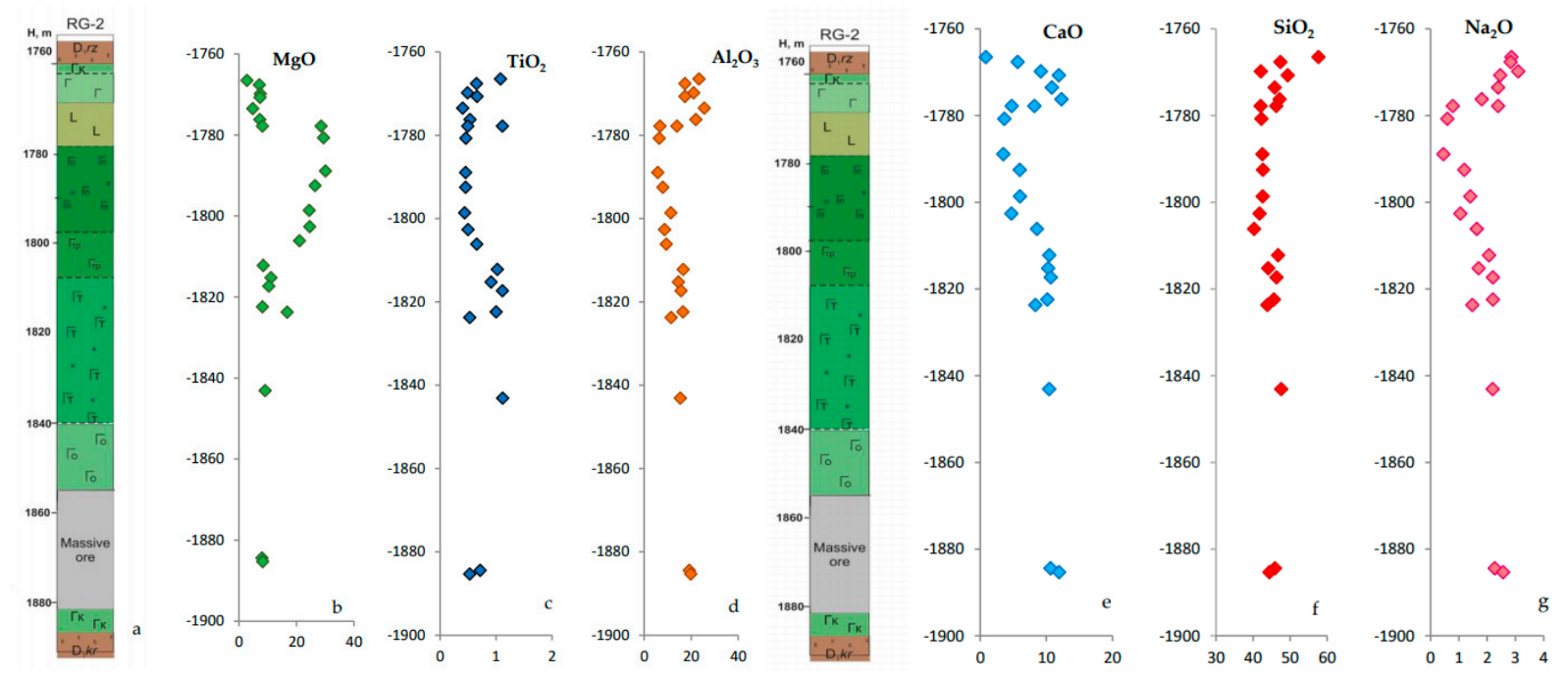

Figure 4. Inner structure of the intrusion (a) and distribution (wt.\%) $\mathrm{MgO}(\mathbf{b}), \mathrm{TiO}_{2}(\mathbf{c}), \mathrm{Al}_{2} \mathrm{O}_{3}(\mathbf{d}), \mathrm{CaO}(\mathbf{e}), \mathrm{SiO}_{2}(\mathbf{f})$ and $\mathrm{Na}_{2} \mathrm{O}$ (g) in its vertical section (borehole RG-2). Captions to Figure 4, gabbro-dolerites: $\Gamma_{\mathrm{K}}-$ contact, $\Gamma_{\mathrm{o}}$-olivine-bearing, $\Gamma_{\mathrm{T}}$-taxtic, $\Gamma_{\Pi}-$ picritic, $\Gamma$-olivine-free, L-leucogabbro.

The lower endocontact zone (at a depth of 1881.4-1889.1 m; here and below, the depths are given according to the RG-2 borehole drilled from an altitude of $+250 \mathrm{~m}$,) is represented by small- to medium-grained gray contact gabbro-dolerites with ophitic and poikilophytic structures. These rocks consist of plagioclase (40-60 vol.\%), clinopyroxene (35-50 vol.\%), olivine (1-3 vol.\%), and sulfides (<1 vol.\%). Plagioclase forms patchy and wide-plate zoned crystals (Figure 5a), and their composition varies from $\mathrm{An}_{45}$ to $\mathrm{An}_{55}$. Clinopyroxene 
is interstitial and its composition corresponds to augite-diopside. Olivine forms small $(0.2-0.3 \mathrm{~cm})$ crystals containing $\mathrm{Fo}_{48-52}$. Sulfide inclusions are $0.2-0.6 \mathrm{~cm}$ grains growing in the space between the rock-forming minerals. The contact gabbro-dolerites comprise a $0.2 \mathrm{~m}$ leucogabbro inclusion.
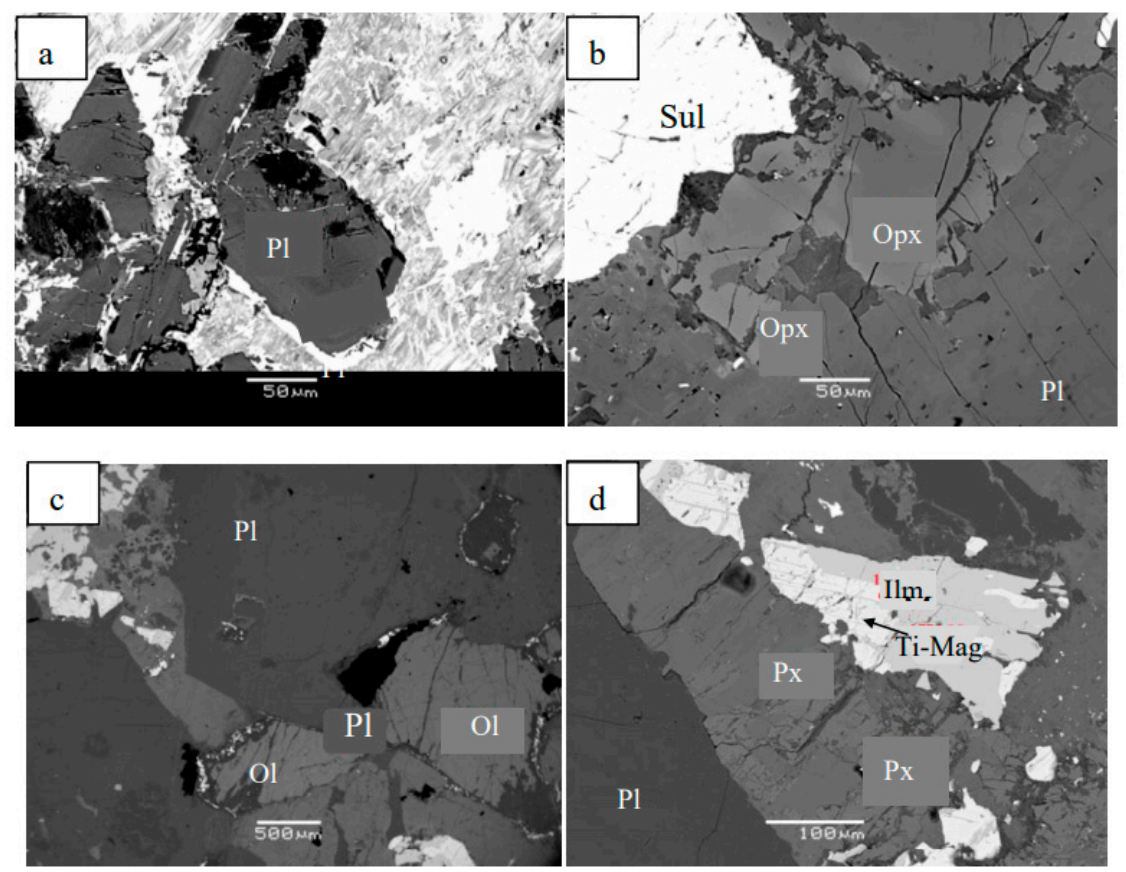

Figure 5. Backscattered electron (BSE) images of intrusive rocks from borehole RG-2: (a) contact gabbro-dolerites (depth $1885 \mathrm{~m}),(\mathbf{b})$ olivine gabbro-dolerite $(1850 \mathrm{~m})$, (c) troctolite $(1803 \mathrm{~m}),(\mathbf{d})$ gabbro-dolerite $(1772 \mathrm{~m})$. Minerals: Pl: plagioclase, Ol: olivine, Px: pyroxene, Opx: orthopyroxene, Sul: sulfides.

Massive sulfide ores (orebody C-5) occur at the depth 854.3-1881.4 m. Their lower contact with gabbro-dolerites is characterized by numerous fractures, whereas their upper contact with olivine gabbro-dolerite is sharp (Figure $5 b$ ).

At the depth between 1823.0 and $1854.2 \mathrm{~m}$, gabbro-dolerites have an ataxitic texture and are characterized by non-uniform crystalline rock that varies from fine-grained to coarse-grained. Plagioclase dominates in coarse-grained rocks, whilst fine-grained aggregates mostly consist of pyroxene and olivine. The fine-grained melanocratic aggregates (up to $20 \mathrm{vol} . \%$ ) occur as inclusions $(5-6 \mathrm{~cm})$ in leucocratic varieties corresponding to leucogabbro. Olivine in these rocks contains $\mathrm{Fo}_{68-72}$. Plagioclase compositions vary from $\mathrm{An}_{68}$ to $\mathrm{An}_{82}$. The rocks contain up to $10 \%$ disseminated sulfides that are irregularly distributed. Their morphology depends on the constitution of silicate rock-forming minerals, and their size varies from 0.5 to $4-5 \mathrm{~cm}$.

High-magnesium rocks, e.g., picritic gabbro-dolerites and troctolites (Figure 5c), form a $20 \mathrm{~m}$ thick horizon at the depth 1778-1798 m. The rocks are dark-gray or black, smallto medium-grained with massive structure and hypidiomorphic and poikilitic textures. They consist of (vol.\%) olivine (40-60), plagioclase (40-60), and clinopyroxene, for which its maximum abundance (30\%) is observed in picritic gabbro-dolerites. Orthopyroxene (up to $3 \%$ ), chromium spinel (1-3\%) and sulfides (up to $7-10 \%$ ) also occur in the rocks. The morphology of olivine grains varies from small rounded grains enclosed by plagioclase to large idiomorphic crystals. Its composition varies from $\mathrm{Fo}_{76}$ to $\mathrm{Fo}_{82}$ in the $\mathrm{Mg}$-rich rock, and also contains variable contents of Ni, $\mathrm{Mn}$ and $\mathrm{Ca}$ (Table 1). Plagioclase forms laths and large tabular crystals. The plagioclase composition varies significantly even within a single sample, from $\mathrm{An}_{50}$ to $\mathrm{An}_{88}$. Pyroxene composition corresponds to diopside-augite. Large olivine grains are fractured forming $0.2-0.3 \mathrm{~cm}$ blocks partially replaced by serpentine. 


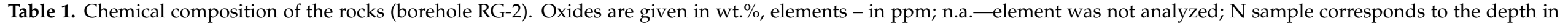
borehole RG-2.

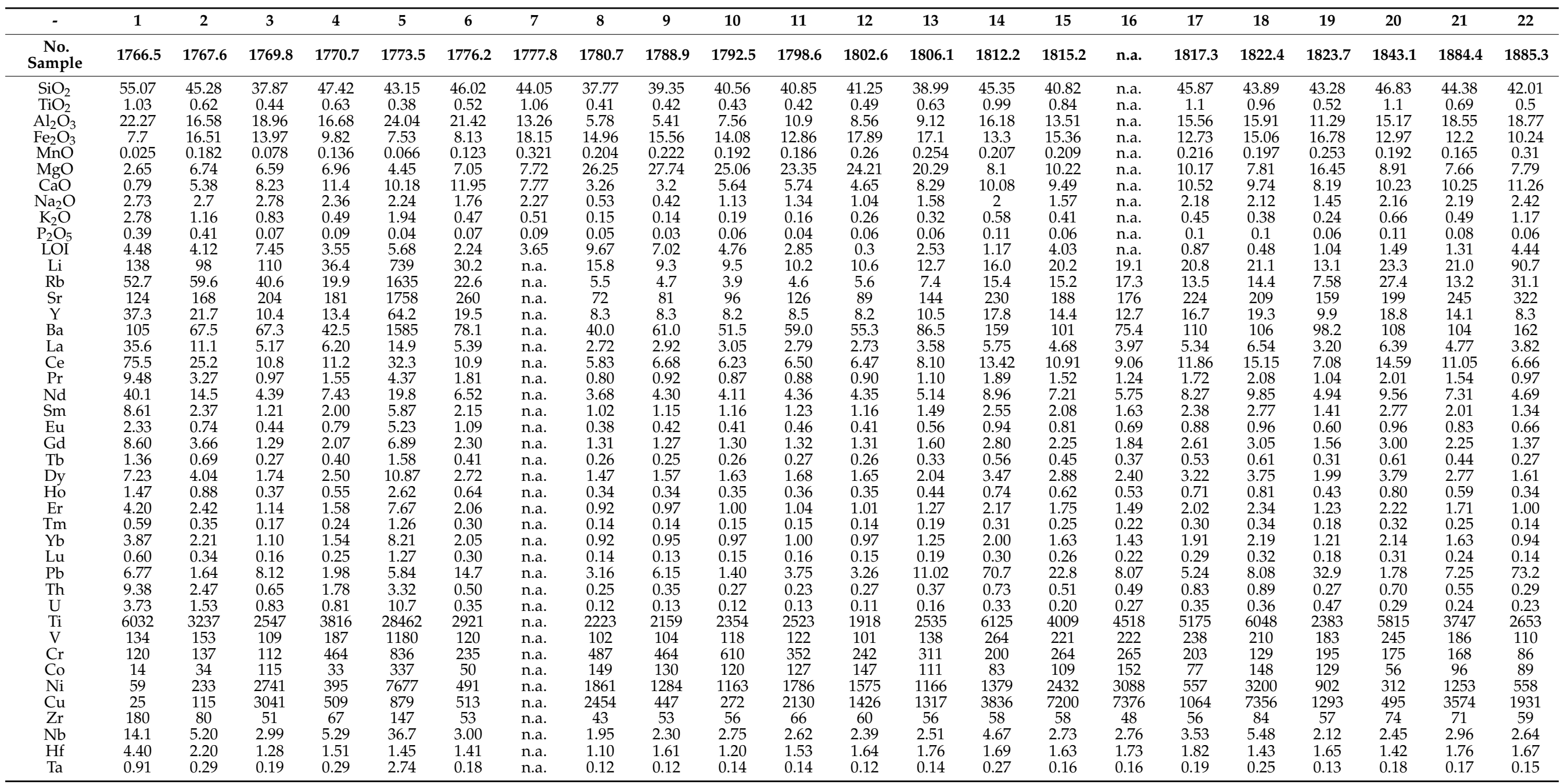


The upper part of this section (at the depth of 1764.5-1778.1 m) comprises of layers of rocks of different compositions, including leucogabbros, ferrogabbros, and olivine gabbrodolerites (Figure 5d). Leucogabbro (1770.1-1778.2 m) is light-gray middle- or large-grained rock which contains tabular plagioclase crystals $(>70 \%)$, that often show twinning, whereas some grains show zoning. Plagioclase forms 1 to $5 \mathrm{~mm}$ grains with variable composition, such that oligoclase $\left(\mathrm{Pl}_{15-25}\right)$, andesine $\left(\mathrm{Pl}_{40}\right)$, and labrador $\left(\mathrm{Pl}_{65}\right)$. Plagioclase has often undergone a secondary alteration (saussuritization), more often in its core. Secondary minerals are chlorite and sericite. Orthopyroxene (15\%) and clinopyroxene $(10 \%)$ are often also exhibited secondary replacements by amphibole. Accessory minerals include ilmenite, titanite, biotite, apatite, and rutile.

Ferrogabbro is a medium-grained grey rock, with porphyric texture due to large titanomagnetite crystals in a massive matrix composed of plagioclase and pyroxene. The titanomagnetite abundance reaches to 7-10 vol.\%. Olivine gabbro-dolerites consist of (vol.\%): clinopyroxenes ( 35), orthopyroxene (5-10), plagioclase (45-50), and olivine (5-7). The size of pyroxene grains varies from $0.3 \mathrm{~mm}$ to $2.5-3 \mathrm{~mm}$. Pyroxene forms zoned grains. Its central part is enriched in $\mathrm{Cr}$ (green color), while its rim contains high Ti concentrations (brown color). Clinopyroxene is replaced by amphibole of the actinolite-tremolite series. Accessory minerals include apatite, titanomagnetite, ilmenite, rutile, and sulfides, whereas, biotite, chlorite, amphibole constitute secondary minerals.

\subsection{Whole Rock Compositions}

\subsubsection{The Distribution of Major Components}

Variation in mineral composition is reflected in host rocks chemistry. The concentrations of rock-forming oxides occur over the following intervals (wt.\%): $\mathrm{SiO}_{2}$ 37.8-55.1, $\mathrm{TiO}_{2}$ 0.38-1.10, $\mathrm{Al}_{2} \mathrm{O}_{3}$ 5.4-24.0, $\mathrm{Fe}_{2} \mathrm{O}_{3}$ 7.53-18.2 (total Fe is expressed as $\mathrm{Fe}_{2} \mathrm{O}_{3}$ ), $\mathrm{MnO}$ 0.03-0.32, MgO 2.65-27.7, $\mathrm{CaO} 0.79-11.95, \mathrm{Na}_{2} \mathrm{O} 0.42-2.78, \mathrm{~K}_{2} \mathrm{O} 0.14-2.78, \mathrm{P}_{2} \mathrm{O}_{5} 0.03-0.41$. Variations in the chemistry of the whole rocks with depth (borehole RG-2) are shown in Figure $4 \mathrm{~b}-\mathrm{g}$. Leucogabbro found in the lower contact of the intrusion is characterized by elevated content (wt.\%) of $\mathrm{CaO}$ (11.3), $\mathrm{Al}_{2} \mathrm{O}_{3}$ (18.5), $\mathrm{Na}_{2} \mathrm{O}$ (2.24), and $\mathrm{K}_{2} \mathrm{O}$ (1.17), and a low content of $\mathrm{TiO}_{2}$ (0.5). Olivine gabbro-dolerites overlaying the massive ore are characterized by higher contents of $\mathrm{MgO}$ (8-10 wt.\%) than the contact gabbro-dolerites. This range of $\mathrm{MgO}$ concentrations of the olivine gabbro-dolerites comparable to that of the overlying taxitic gabbro-dolerites (Figure 4b). The $\mathrm{MgO}$ content increases from 9 to $16 \mathrm{wt} \%$ from the bottom to the center of this horizon. In the same direction $\mathrm{Fe}_{2} \mathrm{O}_{3}$ increases from 13 to $17 \mathrm{wt} . \%$ and $\mathrm{TiO}_{2}$ from 0.5 to $1 \mathrm{wt} . \%$ (Figure $4 \mathrm{c}$ ). $\mathrm{Al}_{2} \mathrm{O}_{3}$ content changes from 11 to 18.5 wt.\% (Figure $4 \mathrm{~d}$ ) and $\mathrm{CaO}$ grows from 8 to 10 wt.\% (Figure 4e). $\mathrm{SiO}_{2}$ concentration does not vary significantly (43-47 wt.\%, (Figure $4 \mathrm{f})$ ). The changes in elemental compositions of rocks occur from the bottom to the top in consistent with an increasing of the plagioclase abundance.

The highest $\mathrm{Mg}$ contents (20 to $28 \mathrm{wt}$ \%) were measured in picritic gabbro-dolerites and troctolites, respectively (Figure $4 \mathrm{~b}$ ). The $\mathrm{SiO}_{2}$ contents in these rocks are lower than that of the underlying rocks (Figure $4 \mathrm{e}$ ). $\mathrm{Fe}_{2} \mathrm{O}_{3}$ in the picritic gabbro-dolerites is constant (14-15 wt.\%), whereas it increases to $17 \mathrm{wt} \% \%$ in troctolites. The $\mathrm{Al}_{2} \mathrm{O}_{3}$ content in troctolites (9-11 wt.\%), is lesser than that in the picritic gabbro-dolerites (5.5 to $7.5 \mathrm{wt} . \%$ ) as the amount of plagioclase decreases in these rocks. Similarly, the $\mathrm{Na}_{2} \mathrm{O}$ content is lower in troctolites (1.58 wt.\%) in comparison to the picrite gabbro-dolerites (1.13 wt.\%).

Maximum variations of $\mathrm{Fe}, \mathrm{Ti}, \mathrm{Ca}, \mathrm{K}$ and $\mathrm{Na}$ alkalifies are observed in the upper part of the section due to the alternation of thin (1-2 to $5 \mathrm{~m}$ ) layers of titanomagnetiterich (ferrogabbro) and plagioclase-rich (leucogabbro) rocks. However, these rocks are relatively poor in $\mathrm{MgO}$ (4-7 wt.\%). The highest $\mathrm{Al}_{2} \mathrm{O}_{3}$ content (24 wt.\%) was measured in leucogabbro. At the depth of $1766.5 \mathrm{~m}$, the highest contents of $\mathrm{SiO}_{2}\left(55.1\right.$ wt.\%) and $\mathrm{Na}_{2} \mathrm{O}$ (2.7 wt.\%, Figure $4 \mathrm{~g}$ ), as well as the lowest $\mathrm{MgO}$ content (2.7 wt. \%), were determined in upper contact gabbro-dolerites. 


\subsubsection{The Distribution of Trace Elements}

The primitive mantle-normalized spider diagrams (Figure 6) show positive $\mathrm{Pb}, \mathrm{U}$, $\mathrm{Sr}$, and, in some cases, Eu anomalies in various rocks occurring in different depths of the massif. A clear negative $\mathrm{Ta}-\mathrm{Nb}$ anomaly is characteristic of all rocks. The $\mathrm{La} / \mathrm{Yb}$, $\mathrm{La} / \mathrm{Sm}$, and $\mathrm{Gd} / \mathrm{Yb}$ ratios (Table 1) are almost identical throughout the stratigraphy of the intrusion.
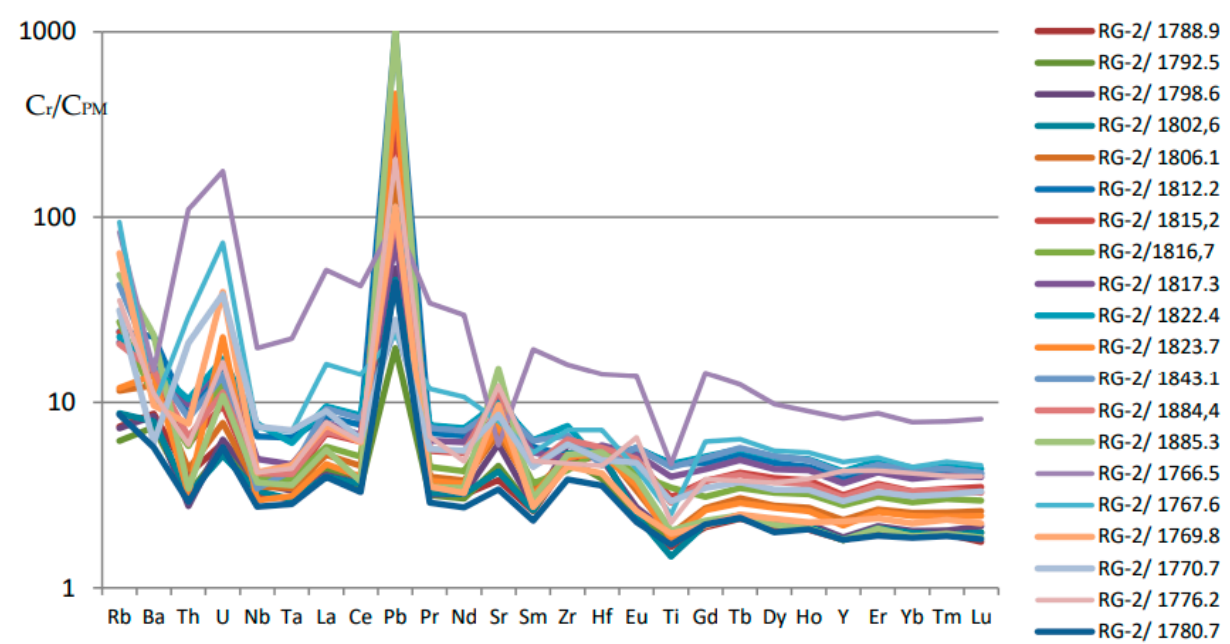

Figure 6. Spider-diagram for intrusive rocks penetrated by borehole RG-2. Normalized to primitive mantle after [40]. Data in Table 1.

Only two samples collected at 1766.5 and $1767.6 \mathrm{~m}$ depths contain high La and Gd concentrations, which have likely resulted in the high $\mathrm{La} / \mathrm{Yb}$, and $\mathrm{La} / \mathrm{Sm}$ ratios (Figure 6). This phenomenon is probably related to the assimilation of host rocks by gabbroic magma, since mudstones and marls are significantly enriched in La (27-29 ppm) in comparison to a magmatic melt (2-5 ppm) [38]. Partially, this enrichment in La could be caused by melt fractionation and appearance of many apatite grains. The lowest contents of trace elements belong to ferrogabbro which is enriched in titanomagnetite.

Maximum variations of iron, titanium, calcium, and alkalis are observed in the upper part of the section due to the alternation of thin (1-2 to $5 \mathrm{~m}$ ) layers of rocks enriched in titanomagnetite and leucogabbro.

\subsection{Sulfide Ore}

\subsubsection{Mineral Composition}

\section{Disseminated Ore}

Sulfides are present in all mafic-ultramafic rocks, but their elevated concentrations occur only in the lower and upper parts of the intrusive body. The first level of high sulfide concentrations coincides with picritic and taxitic gabbro-dolerites horizons, as well as with troctolites. Sulfides are disseminated in the rocks and their contents increase with increasing depth reaching to $20 \mathrm{vol} \%$ in the bottom of the horizons. Sulfide grain sizes also increase downward from $2-4 \mathrm{~mm}$ to $50 \mathrm{~mm}$, especially in taxitic gabbro-dolerites where they form irregular in morphology aggregates. The total thickness of disseminated ores in this drill hole reaches $32 \mathrm{~m}$ and it does not very essentially in this cross section. The ore texture is disseminated or veinlet-disseminated. Sulfide minerals either occur as large aggregates (up to $4-5 \mathrm{~cm}$ ) or small grains in interstitial spaces.

The major ore minerals are pyrrhotite $(55-60 \%)$ and chalcopyrite $(45-50 \%)$, whereas, pentlandite, and cubanite are subordinate. Sphalerite ( $\mathrm{ZnS})$, millerite (NiS), froodite $\left(\mathrm{PdBi}_{2}\right)$ and native $\mathrm{Au}$ are also found in trace amounts. Additionally, titanomagnetite and ilmenite occur in sulfide-bearing rocks. Morphology of sulfides is controlled by the geometry of pore spaces between silicate phases (Figure 7). 


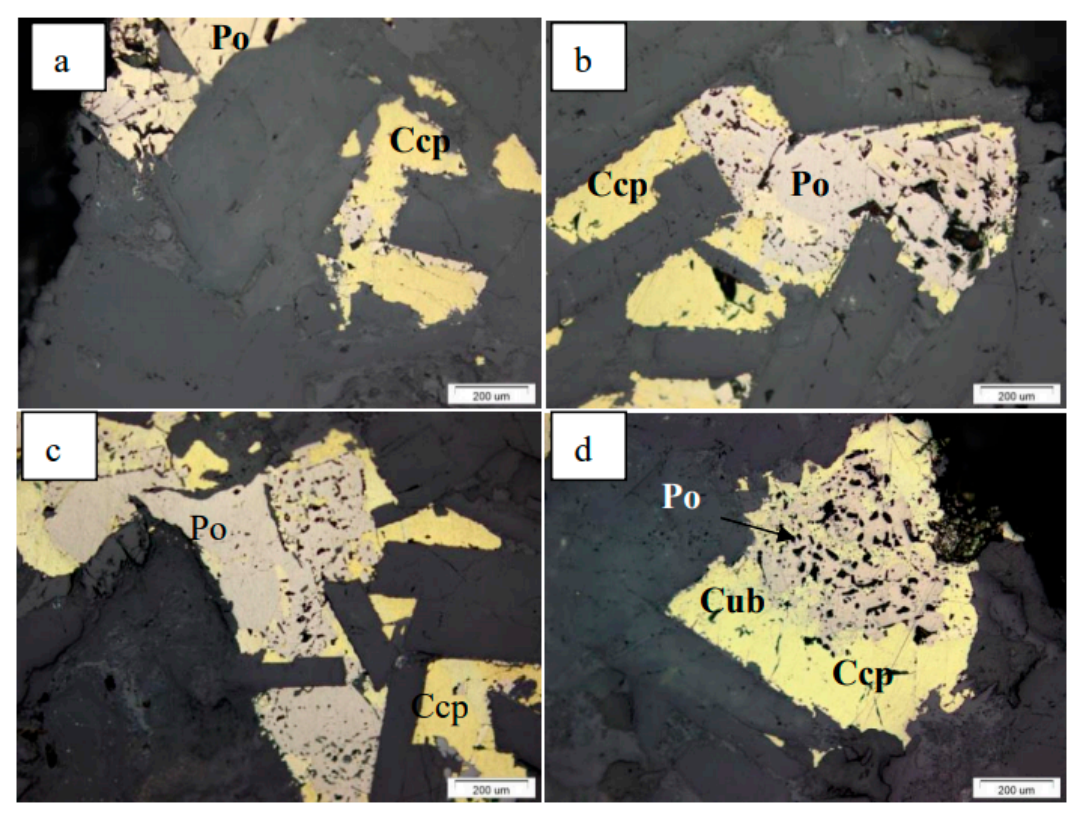

Figure 7. Chalcopyrite-pyrrhotite assemblage in interstitial position between silicate rock-forming minerals, rocks:), (a) olivine gabbro-dolerites (sample RG-2/1840), (b) taxitic gabbro-dolerites (RG-2/1824), (c) troctolites (RG-2/1805), (d) gabbro-dolerites (RG-2/1766), Sample number: borehole/depth, m. Minerals: Po-pyrrhotite $\left(\mathrm{Fe}_{1-\mathrm{xS}}\right), \mathrm{Ccp}$-chalcopyrite $\left(\mathrm{CuFeS}_{2}\right), \mathrm{Cub}$-cubanite $\left(\mathrm{CuFe}_{2} \mathrm{~S}_{3}\right)$.Microphoto in reflected light.

The composition of major minerals especially for chalcopyrite and pyrrhotite is close to stoichiometric (Supplementary Materials, Table S1). Pentlandite is characterized by high $\mathrm{Ni}(35 \mathrm{wt} . \%)$ and Co content varies from 0.4 to $1.6 \mathrm{wt} . \%$.

\section{Massive Ore}

Massive ores, which are $27 \mathrm{~m}$ thick in borehole RG-2, vary vertically in composition. Pyrrhotite commonly dominates in the ore (55-70\%), and forms large anhedral grains. Although chalcopyrite locally prevails, it is rimmed and formed after pentlandite and pyrrhotite. In the massive ore, the content of pentlandite is noticeably higher than in disseminated ores, and sometimes reaches up 25 vol. \%. In addition to rimming chalcopyrite grains, pentlandite occurs as oriented exsolution flames within pyrrhotite (Figure 8e). This textural relationship is commonly observed in magmatic Ni-Cu-PGE deposits, and suggests the crystallization of pyrrhotite and pentlandite from a monosulfide solid solution, or MSS [11,41]. Massive ores are characterized by looped, edged, porphyric, and allotriomorphic textures. Looped textures are significant for ore with a large amount of pyrrhotite: its large grains up to $2-3 \mathrm{~cm}$ in size are surrounded by a chalcopyrite aggregate $(0.2-0.3 \mathrm{~cm}$ wide) (Figure $8 \mathrm{a})$, or this texture occurs in chalcopyrite-pentlandite associations (Figure $8 b$ ). In turn, chalcopyrite grains are bordered by pentlandite (Figure 8c,d), which forms flame-like segregations towards the surrounding pyrrhotite aggregate (Figure 8e). Pentlandite also forms large (up to $0.5 \mathrm{~cm}$ ) idiomorphic crystals among pyrrhotite (Figure 8f) or on its border with chalcopyrite (Figure 8g,h); it also occurs as lenses in large pyrrhotite grains, often together with chalcopyrite (Figure 8e).

Magnetite also occur in massive ore (1-5\%) (Figure 9). According to the classification of Duran et co-authors [42] this type of magnetite corresponds to the first type described in the Norilsk deposits ( $\mathrm{Cu}$-poor sulfide ore, MSS magnetite). Magnetite occurs as anhedral grains, though part of the grains has preserved their original cubic shape. Its morphology and grain size vary. It was found as cubic crystals (square or octagonal in cross-sections in the plane (Figure 9a,b), sometimes elongated crystals (Figure 9c)).More often magnetite grains have a horseshoe shape (Figure $9 \mathrm{e}$ ) and are bordered by pentlandite (Figure $9 \mathrm{~d}, \mathrm{f}$ ). They correspond 
pure stechiometric magnetite containing $0.03 \mathrm{wt} . \% \mathrm{TiO}_{2}$. It seems that this magnetite was among the latest crystallized in this ore mineral sequences because the pentlandite exsolution flames in surrounding pyrrhotite appeared around magnetite grains under subsolidus conditions. Very often similar lamellas occur in pyrrhotite around late cracks in ores.
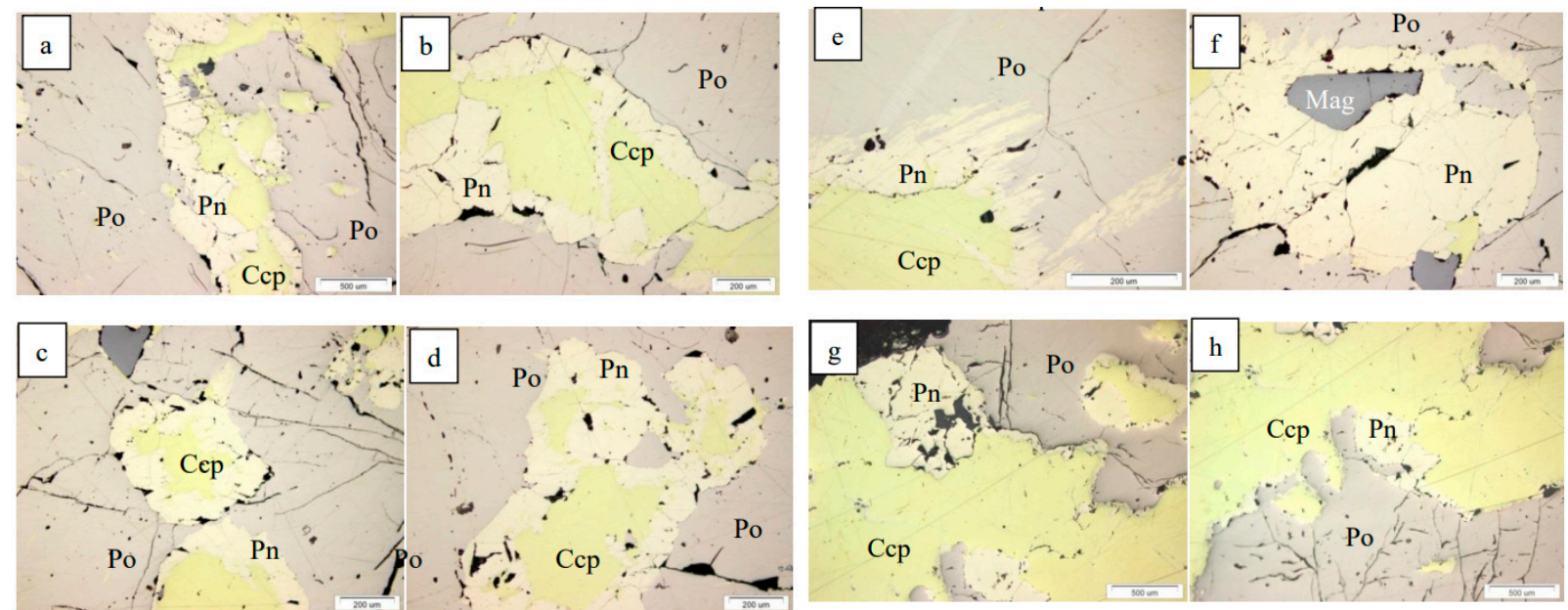

Figure 8. Photomicrographs (reflected light) of the massive ore from the orebody C-5. (a) fragment of looped texture of chalcopyrite-pyrrhotite aggregate, (b) looped texture of pentlandite-chalcopyrite association, (c,d) fire-like grains on the chalcopyrite-pyrrhotite boundary, (e) flame-like segregations towards the surrounding pyrrhotite aggregate; (f) porhyric pentladite crystal in pyrrhotite, (g) ideomorphic pentlandite crystal in chalcopyrite, (h) pentlandite grains around pyrrhotite. Here and in Figure: Ccp: chalcopyrite, Po: pyrrhotite, Pn: pentlandite, Mag: magnetite.
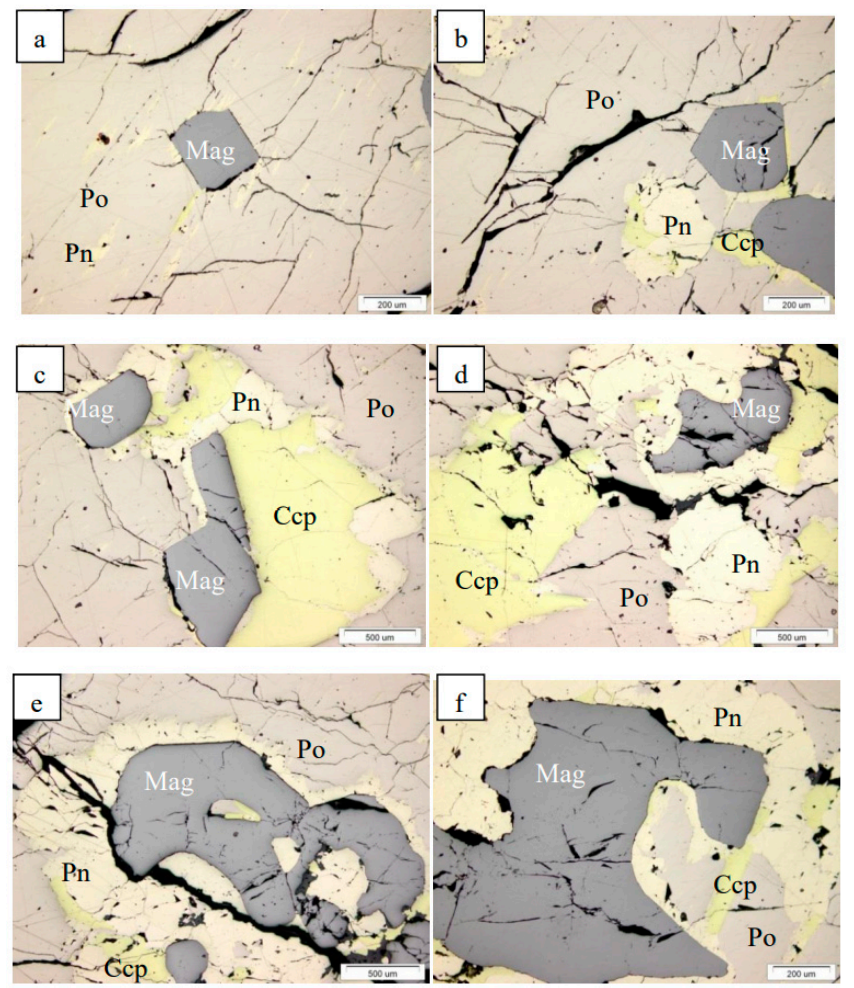

Figure 9. Morphology of the magnetite grains in the massive sulfide ore (orebody C-5). (a) square section of magnetite grain, (b) 5-angle section of grain, (c) rectangular magnetite grain, (d) embayed magnetite grains, (e) embayed magnetite grain with relict of chalcopyrite and pyrrhotite inside, (f) magnetite with pentlandite rim. Microphoto in reflected light. 


\subsubsection{Chemical Composition of Ore}

\section{Disseminated Ore}

Rocks hosting disseminated ore show relative enrichment in $\mathrm{Ni}, \mathrm{Cu}$, and $\mathrm{Co}$, which is consistent with higher abundance of the ore minerals (Figure 10). The two levels of high metals concentrations were distinguished in the borehole RG-2; one at $1773.5 \mathrm{~m}$ depth in leucogabbro, and another in the interval between 1808 and $1822.5 \mathrm{~m}$ in taxitic gabbro-dolerites.

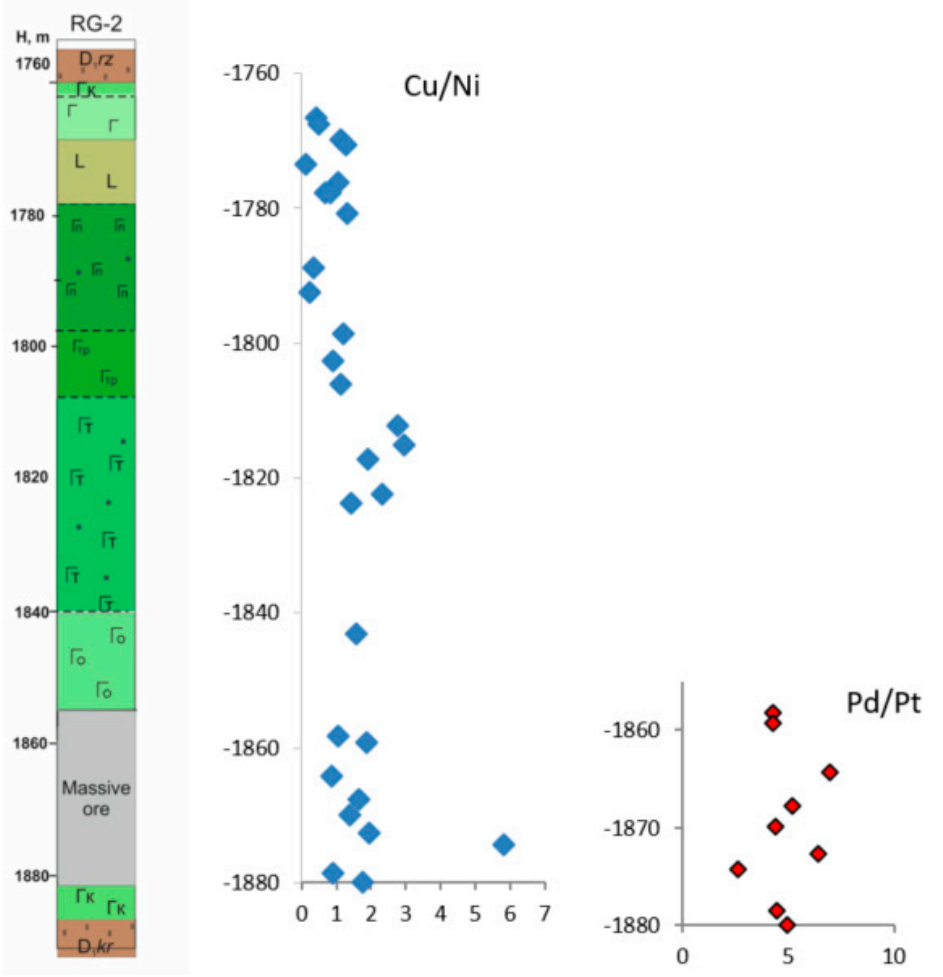

Figure 10. $\mathrm{Cu} / \mathrm{Ni}$ and $\mathrm{Pd} / \mathrm{Pt}$ variations in section of borehole RG-2.

However, in the upper level, $\mathrm{Ni}$ and Co have higher concentrations, whereas in the lower level, the $\mathrm{Cu}$ content predominates in the interval 1808-1822.5 m. These maxima differ from each other in the ratios of elements: the upper one is dominated by $\mathrm{Ni}$ and $\mathrm{Co}$, while the lower one is dominated by $\mathrm{Cu}$. This reflects the composition of ore mineral assemblage as in the upper part of the sequence, the pentlandite-pyrrhotite association is more abundant than chalcopyrite, for which its concentration increases with depths. In picritic gabbro-dolerites and troctolites, the metal content is lower than that measured in leucogabbro and taxitic gabbro-dolerites, and they differ mainly in their $\mathrm{Ni}$ concentrations, which can be explained by the abundance of olivine (its concentration is $60 \mathrm{vol} \% \mathrm{Ni}$ content in olivine reaches $0.28 \mathrm{wt} . \% \mathrm{NiO}$ ).

The composition of massive ores was studied through their thickness. Metal concentrations vary within narrow ranges (wt.\%): $\mathrm{Cu} 4.1-14.4$, Ni 2.5-5.1, Co 0.1-0.2 (Table 2; Supplementary B, Table S2). The $\mathrm{Cu} / \mathrm{Ni}$ ratio fluctuates around 1 , with only one outlier reaching 5.8 consistent with the high chalcopyrite content of this sample (Figure 10). The $\mathrm{Cu} / \mathrm{Ni}$ in massive ore is comparable with that in disseminated ore that includes several samples enriched in $\mathrm{Cu}$. Nickel concentrations are in 25 times higher than Co contents, which is sensitive to the proportion of pentlandite. $\mathrm{Pb}$ and $\mathrm{Zn}$ also found occur in the studied samples at the level of $100 \mathrm{ppm}$. 
Table 2. Chemical composition of massive ore (orebody C-5).

\begin{tabular}{|c|c|c|c|c|c|c|c|c|c|c|c|c|c|c|c|c|c|c|c|c|c|}
\hline $\mathbf{N}$ & N Sample & $\mathrm{Cu}$ & $\mathrm{Ni}$ & Co & $\mathrm{Fe}$ & $S$ & $\mathrm{Zn}$ & $\mathbf{P b}$ & Cd & $\mathbf{P t}$ & $\mathbf{P d}$ & Rh & $\mathbf{R u}$ & Ir & $\mathrm{Au}$ & Ag & As & Te & Se & $\mathrm{Cu} / \mathrm{Ni}$ & $\mathbf{P d} / \mathbf{P t}$ \\
\hline 1 & $\begin{array}{c}\text { RG- } \\
2 / 1858.2\end{array}$ & 5.14 & 4.97 & 0.174 & 54.2 & 28.5 & 251 & 130 & 2.74 & 2.6 & 11.16 & 0.04 & 0.28 & $<0.1$ & 0.1 & 5.31 & 25.4 & 0.96 & 35.8 & 1.0 & 4.3 \\
\hline 2 & $\begin{array}{c}\text { RG- } \\
2 / 1859.3\end{array}$ & 7.31 & 3.94 & 0.134 & 55.7 & 21.7 & 236 & 154 & 3.02 & 2.72 & 11.69 & 0.09 & 1.53 & $<0.1$ & 0.21 & 6.70 & 15.9 & 1.04 & 19.4 & 1.9 & 4.3 \\
\hline 3 & $\begin{array}{c}\text { RG- } \\
\text { 2/1864.3 }\end{array}$ & 4.13 & 4.82 & 0.167 & 55.9 & 24.1 & 86.6 & 123 & 1.18 & 2.44 & 16.97 & 0.5 & 0.20 & 0.44 & 0.32 & 17.7 & 25.3 & 1.17 & 19.2 & 0.9 & 7.0 \\
\hline 4 & $\begin{array}{c}\text { RG- } \\
2 / 1867.7\end{array}$ & 8.12 & 4.89 & 0.155 & 46.6 & 29.5 & 130 & 159 & 2.8 & 2.75 & 14.26 & 0.78 & 0.81 & 0.25 & 0.42 & 17.3 & 26.9 & 1.40 & 32.3 & 1.7 & 5.2 \\
\hline 5 & $\begin{array}{c}\text { RG- } \\
\text { 2/1869.9 }\end{array}$ & 6.96 & 5.01 & 0.172 & 47.0 & 27.3 & 110 & 142 & 2.46 & 3.26 & 14.41 & 0.83 & 0.54 & $<0.1$ & 0.5 & 16.2 & 30.0 & 1.47 & 41.5 & 1.4 & 4.4 \\
\hline 6 & $\begin{array}{c}\text { RG- } \\
2 / 1872.6\end{array}$ & 9.62 & 4.97 & 0.173 & 43.5 & 25.4 & 183 & 164 & 3 & 2.32 & 14.87 & 0.49 & 0.11 & $<0.1$ & 0.043 & 8.21 & 29.2 & 0.77 & 15.8 & 1.9 & 6.4 \\
\hline 7 & $\begin{array}{c}\text { RG- } \\
2 / 1874.3\end{array}$ & 14.4 & 2.48 & 0.251 & 45.6 & 25.2 & 348 & 239 & 5.76 & 3.12 & 17.15 & 0.17 & 0.18 & $<0.1$ & 0.54 & 11.1 & 4.93 & 16.7 & 103 & 5.8 & 2.6 \\
\hline 8 & $\begin{array}{c}\text { RG- } \\
\text { 2/1878.5 }\end{array}$ & 4.65 & 5.06 & 0.176 & 50.1 & 28.4 & 81.8 & 114 & 1.08 & 2.63 & 11.72 & 0.36 & 0.35 & $<0.1$ & 0.12 & 13.5 & 25.0 & 0.34 & 28.4 & 0.9 & 4.5 \\
\hline 9 & $\begin{array}{c}\text { RG- } \\
\text { 2/1879.9 }\end{array}$ & 8.52 & 4.86 & 0.174 & 48.4 & 26.9 & 172 & 160 & 2.07 & 2.96 & 14.72 & 0.086 & 0.38 & $<0.1$ & 0.11 & 14.1 & 25.3 & 0.40 & 31.7 & 1.8 & 5.0 \\
\hline
\end{tabular}

Note: $\mathrm{Cu}, \mathrm{Ni}, \mathrm{Co}, \mathrm{Fe}, \mathrm{S}$ are given in wt.\%, other elements-in ppm.

The concentration of platinum group elements is almost constant across the section, such that the $\mathrm{Pt}+\mathrm{Pd}$ amount varies from 14 to $19 \mathrm{ppm}$. The $\mathrm{Pd} / \mathrm{Pt}$ ratio is slightly higher than in the typical Norilsk ores (around 3, [43]) and ranges from 2.6 to 7, with an average value of 4.8. The Rh contents vary from 0.04 to $0.8 \mathrm{ppm}$, which is significant compared to the variation in the $\mathrm{Pt}$ and $\mathrm{Pd}$ concentrations. Iridium was detected using the applied detection method (see above) only in two samples, where its contents are 0.25 and $0.44 \mathrm{ppm}$ (Table 2). Other precious metals are characterized by low concentrations, especially for $\mathrm{Au}$, with contents varying from 0.04 to $0.5 \mathrm{ppm}$. Silver concentrations are higher than the PGE and $\mathrm{Au}$ and vary from 5.3 to $17.7 \mathrm{ppm}$. In addition, the ore zone is characterized by an increase in the concentrations of Se, As, and Te.

\section{Discussion}

The world class Oktyabr'skoe Cu-Ni deposit is hosted within the Kharaelakh intrusion that is separated from the Talnakh intrusion by the Norilsk-Kharaelakh Fault (Figures 2 and 3). The Oktyabr'skoye deposit comprises of a large sulfide orebody that extends $4 \mathrm{~km}$ long and $2 \mathrm{~km}$ wide (Main orebody, Kh-0, Figure 3). The thickness of massive ore reaches to $54 \mathrm{~m}$, which was determined during exploration. This huge orebody, that has already been mined out, had a zoned structure where the central part was composed of talnakhite $\left(\mathrm{Cu}_{9} \mathrm{Fe}_{8} \mathrm{~S}_{16}\right)$ rimmed by cubanite $\left(\mathrm{CuFe}_{2} \mathrm{~S}_{3}\right)$ and its peripheral zone consisted of pyrrhotite. In general, this orebody was characterized by an elevated copper content. An explanation of the origin of such huge sulfide body associated with $80 \mathrm{~m}$ thick intrusive rocks is a non-trivial task. The most popular model for the genesis of the Oktyabr'skoe deposit is its origin as an open magmatic system where channelized intrusions of magma transport magmas, from reservoirs came to the Earth's surface, and assimilated with the surrounding sulfate-bearing rocks in situ [44-48]. The in situ genesis of sulfides, in the modern chamber, has been criticized by the authors in several studies (e.g., [49-51]). There are two major problems with this model: (1) there is no connection between lavas and intrusions $[5,17,21,49]$, and (2) assimilation as a process to produce sulfides was limited in volume [52-55]. Likhachev suggested, in [52], another hypothesis for the formation of the main orebody. He guesses that this huge orebody is a result of accumulation of sulfides transported by several magma portions from a depth to this one place. There is no evidence of this mechanism as of now, but it is certain that the deposit has a complex structure and consists of several small intrusive bodies. Geochemical, and mineralogical data on western flank support this statement [51] as well as data on north-eastern flank of the deposit (Figure 2b).

\subsection{Intrusive Rocks}

We have compared the new geological and geochemical data with our data obtained earlier from other parts of the Oktyabr'skoe deposit (Figure 3): western (ZF-10 [51]; ZF- 
12 [54]; south-eastern (TG-21 [56]), central (RT-7 [56], RT-101) and northeastern (RG-2, this article). Together, these drillholes indicate the specific inner structure of the intrusion penetrated by RG-2. This intrusive section is characterized by a contrasting differentiated structure where Mg-rich rocks are thick and are associated with leucogabbro. This section does not contain olivine and olivine-bearing rocks, which usually separate picritic gabbrodolerites from leucocratic varieties in the classical sections typical of the central parts of the deposit (see RT-7 and RT-101).

As a result, the average weighted mean composition of the intrusive body, calculated based on data from RG-2 borehole, shows an elevated MgO content (15.4 wt.\%) in comparison with 10-12 wt.\% MgO documented in intrusions of the Norilsk complex [55]. The structure of intrusion penetrated by borehole RG-2 is partially similar to the structure of the western flanks of the deposit where there is also a division into picritic and leucocratic varieties, even sometimes located within independent bodies. The second characteristic feature of silicate rocks in the north-eastern flank is very low abundance of sulfides in Mg-rich rocks, as was noted for the western flanks as well (they also contain massive ores). The occurrence of thick ( $32 \mathrm{~m})$ taxitic gabbro-dolerites containing disseminated ore distinguishes the RG-2 vertical section from intrusions of the western flank. Thus, we assume that studied intrusive section is close to the periphery part of the intrusive body.

Comparing chemical composition of the rocks from different parts of the deposit (western, boreholes ZF-10 and ZF-12; south-eastern, borehole TG-21 and north-eastern, borehole RG-2) shows that they do not have any significant differences (Figure 11). Compositions practically overlap for all oxides. Rocks of the upper endocontact are rich in $\mathrm{Si}$, $\mathrm{Al}$, and $\mathrm{P}$ (Figure 11a,c,h) due simultaneous melt fractionation and local assimilation of surrounding rocks. The similarity in rocks compositions may indicate their genetic link and formation from similar magmas [55]. Almost all intrusions of the Norilsk complex are characterized by similar rock compositions regardless of the sulfide content. The distribution of trace elements in rocks is close in many intrusions, they have patterns with $\mathrm{Nb}$-Ta negative and $\mathrm{Pb}, \mathrm{Sr}, \mathrm{U}$ positive anomalies. In general, the high content of trace elements in rocks of the Norilsk intrusive complex is established, reflecting the degree of fractionation of parental magma. Thus, ore composition provides more useful information to differentiate between intrusive bodies.

\subsection{Massive Ore}

The mineral composition and textural and structural features of the C-5 orebody are quite typical of chalcopyrite-pyrrhotite ores not only from other orebodies of the Oktyabr'skoe deposit, but also from other deposits. For example, similar texture and structure of ore (in particular, a looped texture) are typical of the Talnakh deposit (orebody C-2, intersected by borehole OUG-2).

For a comparison of different parts of the deposit, the chemical composition of related ore was used. Given the lack of data from C-6 orebody (Figure 3), to understand the geology of this area, chemical data from the C-3 and C-4 orebodies were investigated using scatter plots. The given orebodies are located in the immediate vicinity of $\mathrm{C}-5$ to the west and have been penetrated by RT-7 and RT-101 boreholes, respectively (Figure 12). The thicknesses of these massive ores are less than that from RG-2 borehole but they occur very close to each other ( 8.8 and $11 \mathrm{~m}$, respectively). According to their special distribution in the northern part of the deposit, the located nearby C-4 and C- 5 orebodies were expected to share similar characteristics. In contrast, they differ in the main metal contents and their ratios (Supplementary C, Table S3). Copper sharply dominates in the C-4 body causing a much higher $\mathrm{Cu} / \mathrm{Ni}$ ratio $(4.8-7.5)$ than that of the $\mathrm{C}-5$ orebody, in the immediate vicinity of $\mathrm{C}-5(\sim 1)$. The metal $(\mathrm{Ni}, \mathrm{Cu}, \mathrm{Co}, \mathrm{PGE})$ concentration and $\mathrm{Cu}: \mathrm{Ni}$ ratio in $\mathrm{C}-5$ orebody is similar to values for the $\mathrm{C}-3$ orebody, which is also characterized by low $\mathrm{Cu}$ concentration in sulfides and $\mathrm{Cu} / \mathrm{Ni}$ close to 1 (Figure 13a). The total concentration of $\mathrm{Pt}+\mathrm{Pd}$ is much lower in the $\mathrm{C}-3$ and $\mathrm{C}-5$ bodies $(<20 \mathrm{ppm})$ than in the C-4 orebody $(\mathrm{Pt}+\mathrm{Pd}=40-80 \mathrm{ppm})$ (Figure 13b), This applies to both palladium (Figure 13c) and platinum (Figure 13d) sepa- 
rately. However, the $\mathrm{Pd} / \mathrm{Pt}$ ratio in ores does not change significantly from the C-4 orebody (4.1 to 7.5) to C-3 and C-5 (5 to 6). Strong correlations are detected among $\mathrm{Cu}, \mathrm{Pt}$, and $\mathrm{Pd}$ (especially for the C-3 orebody, where for $\mathrm{R}^{2}=0.86$ for $\mathrm{Cu}-\mathrm{Pd}$ trendline). The $\mathrm{Rh}$ content does not show any correlation with $\mathrm{Pt}$ and $\mathrm{Pd}$ (Figure 13f,g), but it depends on nickel concentration. There is also a clear correlation between Co and Ni (Figure 13h), consistent with concentration in pentlandite.
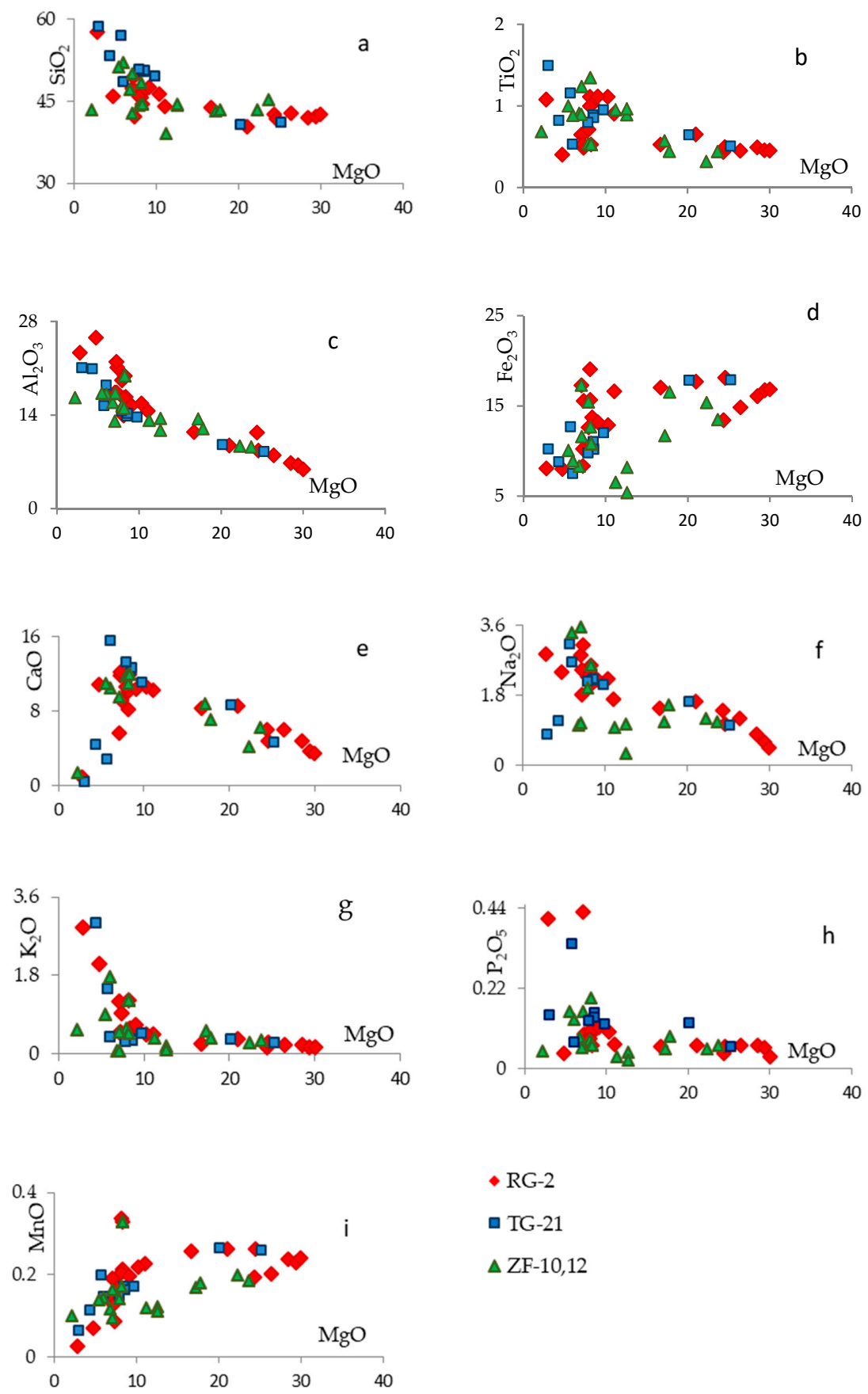

- RG-2

$\square$ TG-21

$\Delta \mathrm{ZF}-10,12$

Figure 11. Diagrams $\mathrm{MgO}-\mathrm{SiO}_{2}(\mathbf{a}), \mathrm{TiO}_{2}(\mathbf{b}), \mathrm{Al}_{2} \mathrm{O}_{3}$ (c), $\mathrm{FeO}(\mathbf{d}), \mathrm{CaO}(\mathbf{e}), \mathrm{Na}_{2} \mathrm{O}(\mathbf{f}), \mathrm{K}_{2} \mathrm{O}(\mathbf{g})$, $\mathrm{P}_{2} \mathrm{O}_{5}$ (h), $\mathrm{MnO}$ (i) (wt.\%), for intrusive rocks of the Oktyabr'skoe deposit (boreholes RG-2, TG-21, ZF-10 + ZF-12). 


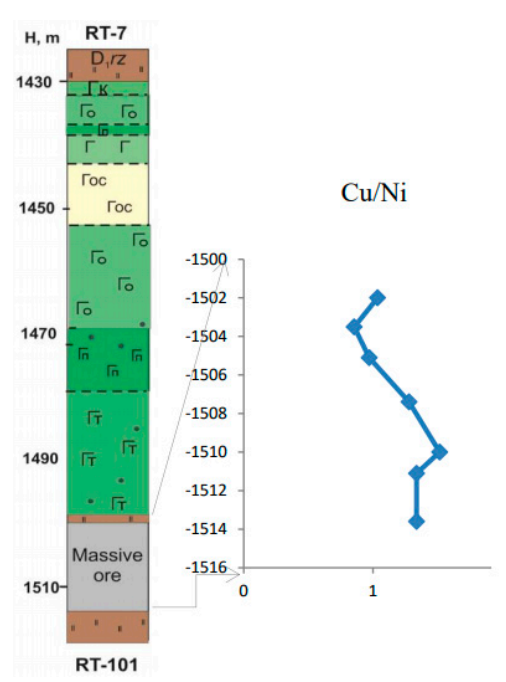

(a)
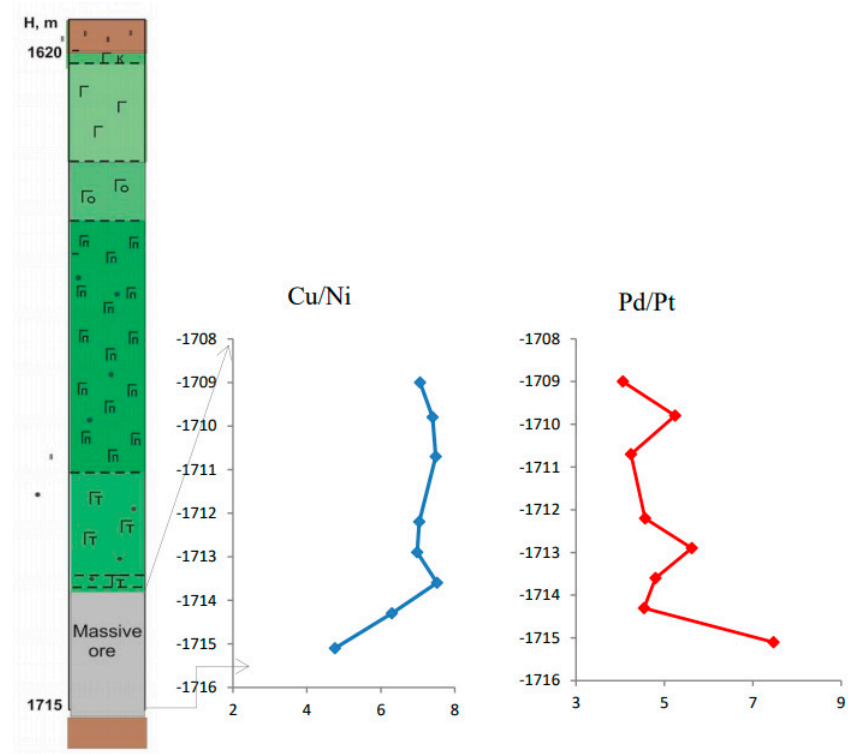

(b)

Figure 12. Intrusive structure and $\mathrm{Cu} / \mathrm{Ni}, \mathrm{Pd} / \mathrm{Pt}$ distribution in massive ore on the borehole RT-7 (C-3 orebody) and RT-101 (C-4 orebody). (a) 1430-1510 m; (b) 1620-1715 m.

In general, it should be noted that the largest variations of elements occur in the C-4 orebody, while C-3 and C- 5 orebodies are characterized by a very consistent ore composition for all components. The Ag contents is about 20 to 50 times greater than $\mathrm{Au}$ and shows no correlations with $\mathrm{Cu}$ or Ni. In contrast, Au shows a positive correlation with $\mathrm{Cu}$.

\subsection{Suggestions on Genetic Model}

Figure $2 \mathrm{~b}$ (cross section), Figure 3 , and Figure 14 (plan) show that intrusive rocks do not cover whole area of the deposit, there are several "windows" and gaps in their occurrence. This structure could be explained by either the injection of a single magma in different directions or multiple magmatic events. Different directions of emplacement were suggested by Stekhin [28] and Likhachev [52].

As mentioned above, to determine the origin of the Oktyabr'skoe deposit it is necessary to obtain comprehensive data on its geological structure and ore composition. Although numerous data were collected during the exploration, they are not available for researches and have not been collected systematically. Therefore, such work should be performed on the existing parts of the field that have not yet been worked out. The structure of the western flanks of the Oktyabr'skoe deposit has been previously studied [51], and this is the second attempt to document the structure of the deposit. 

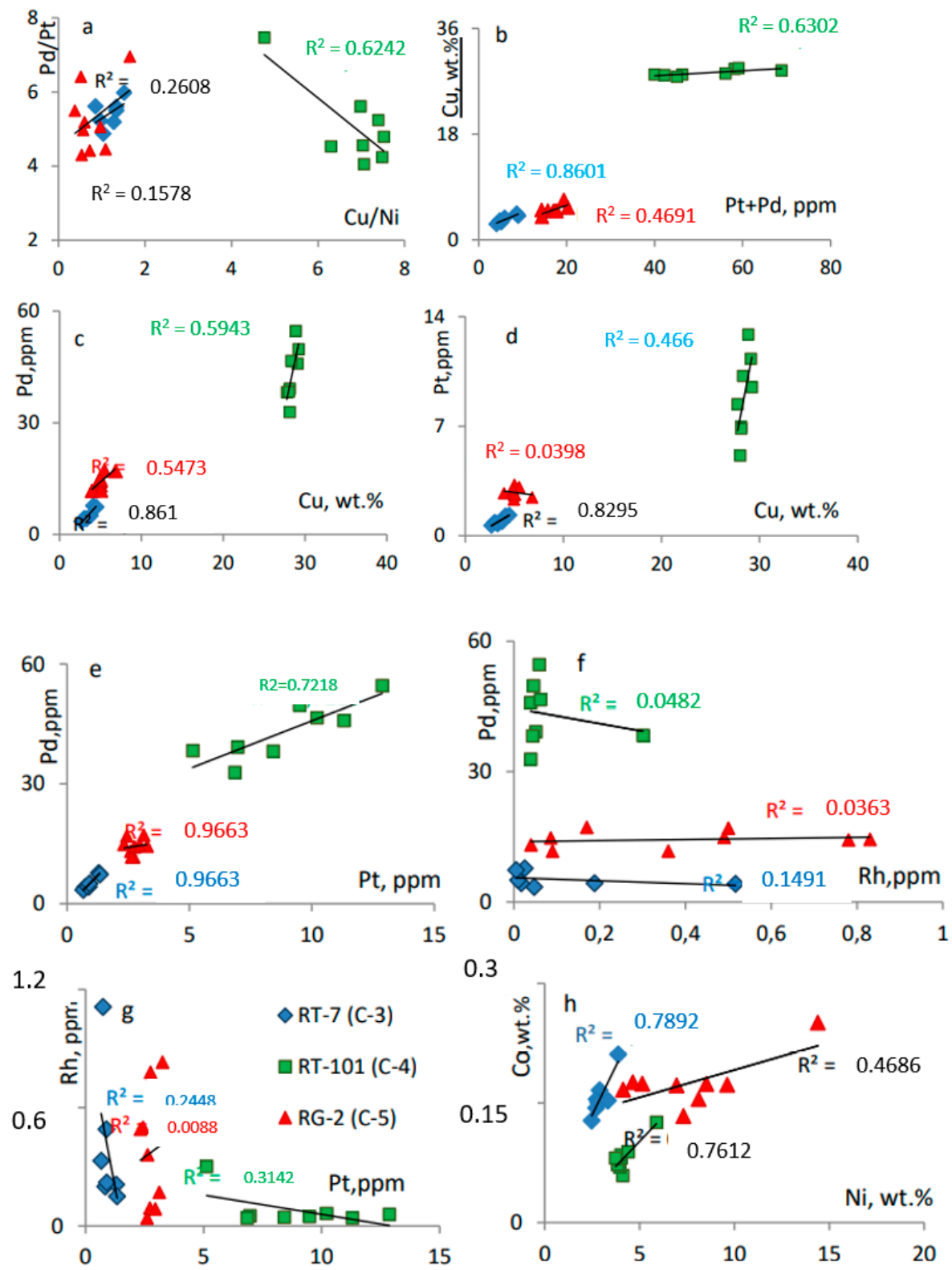

0.3
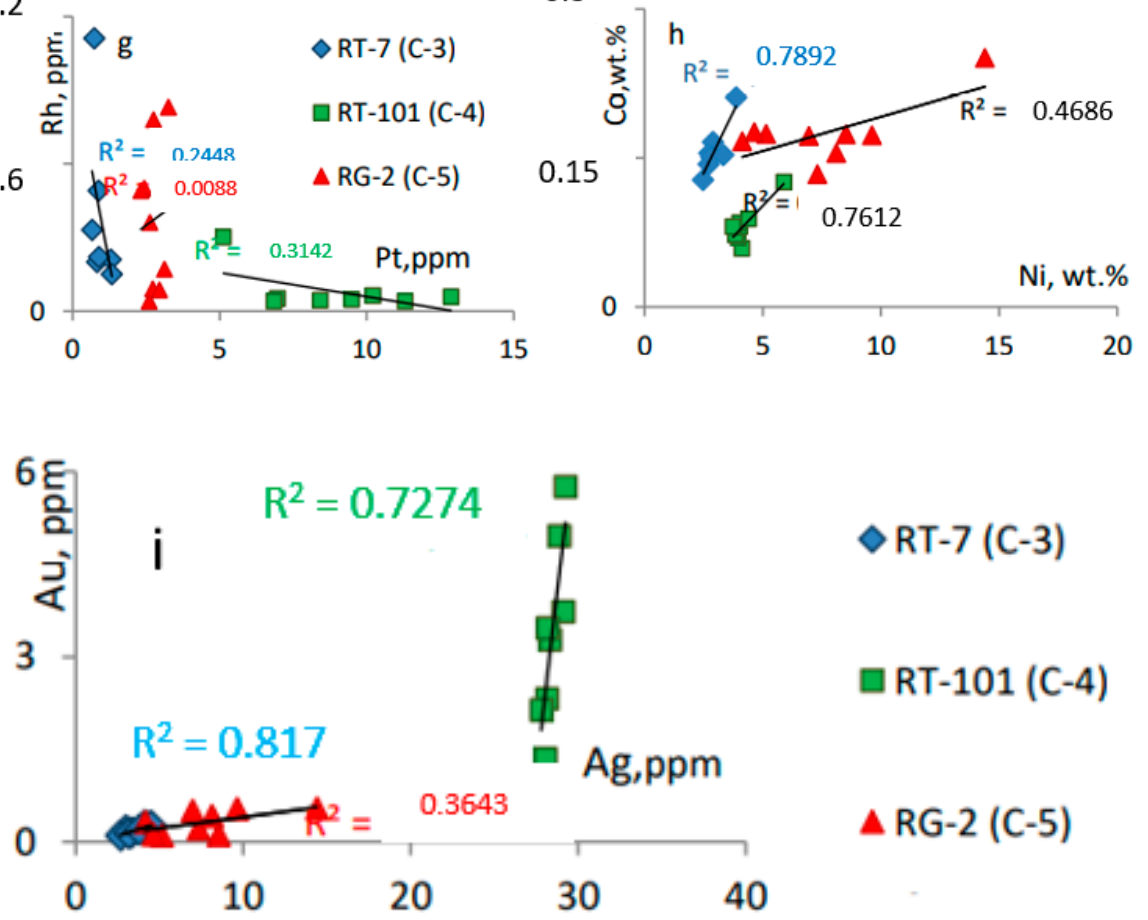

RT-7 (C-3)

RT-101 (C-4)

$\Delta$ RG-2 (C-5)

Figure 13. Relationships of metals in massive sulfide ores in C-3, C-4 and C-5 orebodies. (a) Cu/Ni$\mathrm{Pd} / \mathrm{Pt}$; (b) Pt+Pd-Cu; (c) Cu-Pd; (d) Cu-Pt; (e) Pt-Pd; (f) Rh-Pd; (g) Pt-Rh; (h) Ni-Co; (i) Ag-Au. 


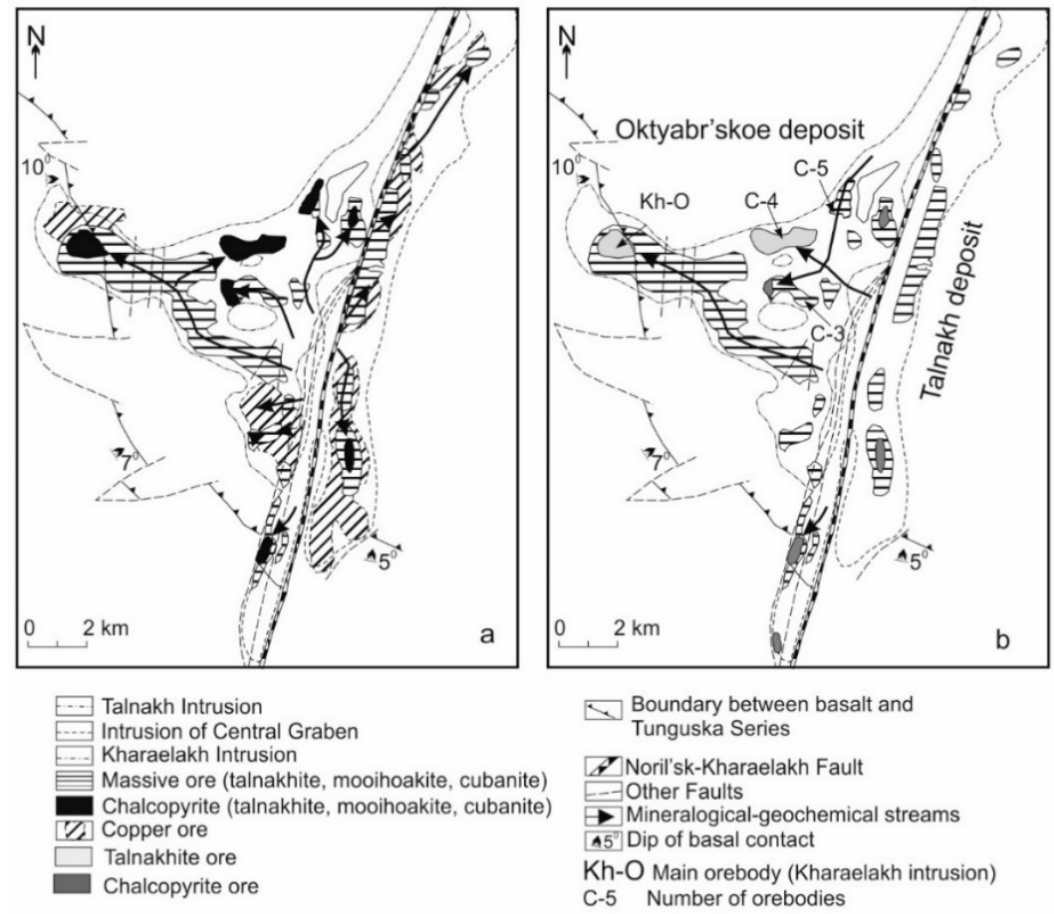

Figure 14. Projection on the surface of the Kharaelakh and Talnakh intrusions and massive ores: (a) after [27], (b) with authors data and interpretation.

The most detailed review of the Oktyabr'skoe deposit structure was made by Stekhin [28], who identified mineral and geochemical "streams" (possible intrusions) within it (Figure 14a). He subdivided ores into following types: copper ore (disseminated ore in the host rocks) and massive ore (talnakhite, mooihoekite, cubanite) and chalcopyrite ore (with talnakhite, mooihoekite, and cubanite). The difference between two last types is not entirely clear, it is possible that massive ores mean chalcopyrite-pyrrhotite (which raises the question of whether this is due to an error in the legend?). This suggestion is based on the zoned structure of the main orebody where the central part is composed of talnakhite rimmed by cubanite and then pyrrhotite. However, even in this interpretation, the division of copper-rich ores into the most important components, i.e., chalcopyrite and talnakhite proper, which differ in the conditions of formation, did not occur. We carried out this analysis on the basis of literature data $[28,29,56]$, as well as our own materials obtained for the western part of the Oktyabr'skoe deposit $[17,28]$, the southern part of the Talnakh deposit (Southern-2 orebody), and data of this article. The C-5 orebody is represented by ordinary chalcopyrite-pyrrhotite ores (Figure 14b), while in Stekhin's scheme (Figure 14a) it is shown as high-Cu body, similar to the C- 4 body. On the basis of our study, we interpret that the C-3 and C -5 orebodies are most likely related to one intrusion whereas the C-4 orebody is associated with a separate intrusion. The dash-dotted line in Figure 3 and lines with arrows in Figure 14 demonstrates the C-3 and C -5 orebodies correlation. The question of whether these bodies belong to the same or different intrusions will be solved later.

Another problem with previous genetic models is the feasibility of transporting large volume of sulfides by a low volume of magma from depths to the surface remains open. The significant progress has been made on this topic due to proposed hypothesis of increasing the transport capacity of magma as a result of its elevated volatile content $[57,58]$. It seems convincing, but it does not reconcile with local Norilsk geology. High fluid-saturated magmas are typical of subduction zones [59-61] while all large $\mathrm{Cu}-\mathrm{Ni}$ deposits are located within platforms where fluid concentrations in magmas are low [62]. So other hypotheses and mechanisms should be made. 


\section{Conclusions}

(1) The intrusive body of the northern flank of the Oktyabr'skoe deposit has a distinctly differentiated structure and is composed of a large volume of high-Mg rocks (picritic gabbro-dolerites and troctolites) having $15 \mathrm{wt} . \% \mathrm{MgO}$ on average. They are combined with the overlaying leucogabbro. The occurrence of a large taxitic gabbro-dolerites $(32 \mathrm{~m})$ horizon is also a distinctive feature of this intrusive sequence.

(2) Sulfide disseminated ores are confined to taxite gabbro-dolerites and are practically not found in high-Mg host rocks. The massive ores forming the $\mathrm{C}-5$ orebody have a thickness of $27 \mathrm{~m}$, and their $\mathrm{Cu} / \mathrm{Ni}$ ratio is about 1 , and $\mathrm{Pd} / \mathrm{Pt}$ varies from 5 to 6 .

(3) The C- 5 body composition is similar to that of the C-3 orebody, and differs from that of the C-4 located nearby. It is assumed that deposits C-3 and C-5 are genetically linked and originate from a single intrusive body, which is different from that hosting the C-4 orebody.

Thus, the Oktyabr'skoe deposit has a complex geological structure composed of several intrusive bodies similar to the Talnakh and Maslovsky deposits. The latter is regarded as a southern continuation of the Norilsk 1 intrusion [50].

Supplementary Materials: The following are available online at https:/ / www.mdpi.com/2075-163 X/11/1/44/s1, Table S1: Chemical composition of the main ore minerals (borehole RG-2); Table S2: Chemical composition of the massive ore (borehole RG-2); Table S3: Chemical composition of massive ore (boreholes RT-7, RT-101).

Author Contributions: Conceptualization, N.K., Y.B.; Investigation, B.G.; Methodology, I.K., O.T. and E.D.; Formal analysis, V.T. All authors have read and agreed to the published version of the manuscript.

Funding: The study of ores of the Oktyabr'skoe deposits was funded by the Russian Foundation for Basic Research, grant No18-05-70094, and composition of intrusive rocks were investigated (analytical work, data collection and interpretation) due to financial support of Ministry of Science and higher education, grant No. 13.1902.21.0018 from the Ministry of the Russian Federation.

Acknowledgments: We are grateful to the geologists of Norilskgeolgy Ltd. for permission for cores sampling. The authors thank N. Svirskaya and V. Turkov for samples preparation, and E. Beskova for her help during the field trip. Recommendations and corrections of the manuscript by two unknown reviewers, and the especially hard and careful work of B. Saumur, helped to improve its quality, for which we thank them very much. We are deeply sorry to inform you that Yana Bychkova, who made a great contribution to this work, suddenly passed away in June 2020.

Conflicts of Interest: The authors declare no conflict of interest.

\section{References}

1. Urvantsev, N.N. North Siberian Ni-bearing province. Russ. Geol. Geophys. 1974, 3, 3-11. (In Russian)

2. Metallogenic Map of the Siberian Platform, 2,500,000 Scale; VSEGEI: Leningrad, Russia, 1984; p. 6. (In Russian)

3. Dodin, D.A. Metallogeny of the Taimyr-Norilsk Region (North Central Siberia); Nauka: St. Petersburg, Russia, 2002; p. 822. (In Russian)

4. Dodin, D.A.; Zoloev, K.K.; Koroteev, V.A.; Chernyshov, N.M. Platinum of Russia: Status and Prospects. In Platinum of Russia; v. 7; Krasnoyarsk: Siberia, Russia, 2011; pp. 12-52. (In Russian)

5. Godlevsky, M.N. Traps and Ore-Bearing Intrusion; Gosgeoltekhizdat: Moscow, Russia, 1959; p. 61. (In Russian)

6. Egorov, V.N.; Sukhanova, E.N. The Talnakh Ore-bearing Intrusion in NW Siberian Platform. Explor. Prot. Miner. Resour. 1963, 17-21. (In Russian)

7. Vaulin, L.L.; Sukhanova, E.N. The Oktyabr'skoe Copper-nickel Deposit. Explor. Prot. Miner. Resour. 1970, 48-52. (In Russian)

8. Zolotukhin, V.V.; Ryabov, V.V.; Vasil'ev, Y.R.; Shatkov, V.A.; Шатков, B.A. Petrology of the Talnakh Differentiated Ore-Bearing Trap Intrusion; Nauka: Novosibirsk, Russia, 1975; p. 243. (In Russian)

9. Budko, I.A.; Kulagov, E.A. New mineral talnakhite—cubic space chalcopyrite. Zap. Vses. Mim Ob-vo 1968, 97, 63-68. (In Russian)

10. Genkin, A.D.; Evstigneeva, T.L.; Ttroneva, N.V.; Vyal'sov, L.P. Polyarite-New mineral from copper-nickel sulfide ore. Zap. Vsev. Mim Ob-vo 1969, 98, 708-715. (In Russian)

11. Kovalenker, V.A.; Genkin, A.D.; Evstigneeva, T.L.; Laputina, I.P. Telargpalite-New mineral of Pd, Ag, and Te from Cu-Ni ores of the Oktyabr'skoe deposit. Zap. Vsev. Mim Ob-vo 1974, 105, 5-6. (In Russian)

12. Begisov, V.D.; Meshankina, V.I.; Dubakina, L.S. Palladarsenide Pd2As-new natural arsenide of palladium from copper-nickel ores of the TheOktyabr'skoe deposit. Zap. Vsev. Mim Ob-vo 1974, 103, 104-107. (In Russian) 
13. Evstigneeva, T.L.; Genkin, A.D.; Kovalenker, V.A. New mineral of Bi and Pd-Sobolevskite and nomenclature of minerals from system PdBi-PdTe-PdSb. Zap. Vsev. Mim Ob-vo 1975, 104, 568-579. (In Russian)

14. Filimonova, A.A.; Evstigneeva, T.L.; Laputina, I.P. Putoranite and Ni-putoranite-New minerals in chalcopyrite group. Zap. Vsev. Mim Ob-vo 1980, 109, 335-341.

15. Genkin, A.D.; Distler, V.V.; Gladyshev, G.D. Sulfide Copper-Nickel Ores of the Norilsk Deposits; Nauka: Moscow, Russia, $1981 ;$ p. 295. (In Russian)

16. Dyuzhikov, O.A.; Distler, V.V.; Strunin, B.M.; Mkrtychyan, A.K.; Sherman, M.L.; Sluzhenikin, S.F.; Lurye, A.M. Geology and Ore Potential of the Noril'sk Ore District; Nauka: Moscow, Russia, 1988; p. 238. (In Russian). Translated in English: Dyuzhikov, O.A.; Distler, V.V.; Strunin, B.M.; Mkrtychyan, A.K.; Sherman, M.L.; Sluzhenikin, S.F.; Lurye, A.M. Geology and metallogeny of sulfide deposits Noril'sk region USSR. In Economic Geology Monograph; Economic Ge-ology Publishing Company: Littleton, CO, USA 1992; 242p.

17. Distler, V.V.; Grokhovskaya, T.L.; Evstigneeva, T.L.; Sluzhenikin, S.F.; Filimonova, A.A.; Dyuzhikov, O.A. Petrology of Magmatic Sulfide Ore Formation; Nauka: Moscow, Russia, 1988; p. 232. (In Russian)

18. Zen'ko, T.E.; Czamanske, G.K. Special and Petrologic Aspects of the Noril'sk and Talnakh Ore Junctions. In Proceedings of the Sudbury-Noril'sk Symposium Ontario; OGS: Sudbury, ON, Canada, 1994; pp. 263-282.

19. Naldrett, A.J.; Fedorenko, A.; Lightfoot, P.C.; Kunilov, E.; Gorbachev, N.S.; Doherty, W.; Johan, Z. Ni-Cu-PGE deposits of the Noril'sk region, Siberia: Their formation in conduits for flood basalt volcanism. Trans. Inst. Min. Metall. Lond. 1995, 104, B18-B36.

20. Likhachev, A.P. Kharaelakh intrusion and its Pt-Cu-Ni ores. Rudy Met. 1996, 3, 48-62. (In Russian)

21. Arndt, N.T.; Czamamanske, G.K.; Walker, R.J.; Chauvel, C.; Fedorenko, V.A. Geochemistry and origin of the intrusive hosts of the Noril'sk-Talnakh Cu-Ni-PGE sulfide deposits. Econ. Geol. 2003, 98, 495-515. [CrossRef]

22. Spiridonov, E.M.; Kulagov, E.A.; Serova, A.A.; Kulikova, I.M.; Korotaeva, N.N.; Sereda, E.V.; Tushentsova, I.N.; Belyakov, S.N.; Zhukov, N.N. Genetic Pd, Pt Au, Ag, Rh mineralogy in Noril'sk sulfide ores. Geol. Ore Depos. 2015, 57, 402-432. [CrossRef]

23. Gritsenko, Y.D.; Spiridonov, E.M. Maucherite of the metamorphogenic-hydrothermal assemblages of Noril'sk ore field. Geol. Ore Depos. 2008, 7, 590-598. [CrossRef]

24. Marfin, A.E.; Ivanov, A.V.; Abramova, V.D.; Anziferova, T.N.; Radomskaya, T.V.; Yakich, T.Y.; Bestemyanova, K.V. A trace element classification tree for chalcopyrite from Oktyabrsky deposit, Norilsk-Talnakh ore district, Russia: LA ICPMS study. Minerals 2020, 10, 716. [CrossRef]

25. Dodin, D.A.; Batuev, B.N. Geology and Petrology of the Talnakh Differentiated Intrusions and their Metamorphic Aureole. In Petrology and Resource Potencial of the Talnakh and Nprilsk Differentiated Intrusions; Nedra: Leningrad, Russia, 1971; pp. 31-100. (In Russian)

26. Krivolutskaya, N.; Tolstykh, N.; Kedrovskaya, T.; Naumov, K.; Kubrakova, I.; OksanaTutunnik, O.; Gongalsky, B.; Kovalchuk, E.; Magazina, L.; Bychkova, Y.; et al. World-class PGE-Cu-Ni Talnakh Deposit: New Data on the Structure and Unique Mineralization of the South-Western Branch. Minerals 2018, 8, 124. [CrossRef]

27. Stekhin, A.I. Mineralogical and Geochemical Characteristics of the Cu-Ni Ores of the Oktyabr'skoe and Talnakh Deposits. In Proceeding of the Sudbury-Norilsk Symposium; OGS: Sudbury, ON, Canada, 2004; Volume 5, pp. 217-230.

28. Likhachev, A.P. Ore-bearing Intrusions of the Norilsk Region. In Proceedings of the Sudbury-Norilsk Symposium; OGS: Sudbury, ON, Canada, 1994; Volume 5, pp. 217-230.

29. Lyul'ko, V.A. (Ed.) Legend for 1: 50000 Scale Map, Noril'sk Group; Geoinformmark: Moscow, Russia, 1993; p. 53. (In Russian)

30. State Geological Map of Russian Federation, 1:1000000 Scale (New Version). R-(45)-47-Norilsk. Explanatory Note; VSEGEI: St. Petersburg, Russia, 2000; p. 479. (In Russian)

31. Zolotukhin, V.V.; Vilensky, A.M.; Dyuzhikov, O.A. Basalts of the Siberian Platform; Nauka: Novosibirsk, Russia, 1986 ; p. 245. (In Russian)

32. Zolotukhin, V.V.; Al'mukhamedov, A.I. Basalts of the Siberian Platform: Composition and Mechanism of Formation. In Traps of Siberia and Deccan: Similarities and Differences; Nauka: Novosibirsk, Russia, 1991; pp. 7-39. (In Russian)

33. Lightfoot, P.C.; Hawkesworth, C.J.; Hergt, J.; Naldrett, A.J.; Gorbachev, N.S.; Fedorenko, V.A. Remobilisation of the continental lithosphere by a mantle plume: Major-, trace-element, and $\mathrm{Sr}-, \mathrm{Nd}-$, and $\mathrm{Pb}$-isotopic evidence from picritic and tholeiitic lavas of the Noril'sk District, Siberian Trap, Russia. Contrib. Miner. Pet. 1993, 114, 171-188. [CrossRef]

34. Ryabov, V.V.; Shevko, A.Y.; Gora, M.P. Trap Magmatism and Ore Formation in the Siberian Noril'sk Region; Springer: Berlin/Heidelberg, Germany, 2014; Volumes 1,2.

35. Kamo, S.L.; Czamanske, G.K.; Amelin, Y. Rapid eruption of Siberian flood-volcanic rocks and evidence for coincidence with the Permian-Triassic boundary and mass extinction at 251 Ma. Earth Plan. Sci. Let. 2003, 214, 75-91. [CrossRef]

36. Strunin, B.M. Geological Map of the Norilsk Area, 1:200,000 Scale; Committee of Russian Federation on Geology and Use of Mineral Resources: Krasnoyarsk, Russia, 1994.

37. Krivolutskaya, N.; Belyatsky, B.; Gongalsky, B.; Dolgal, A.; Lapkovsky, A.; Bayanova, T. Petrographical and Geochemiscal Characteristics of Magmatic Rocks in the Northwestern Siberian Traps Province, Kulyumber River Valley. Part II: Rocks of the Kulyumber Sites. Minerals 2020, 10, 409. [CrossRef]

38. Tyutyunnik, O.A.; Nabiullina, S.N.; Anosova, M.O.; Kubrakova, I.V. Determination of Trace Amounts of Platinum Group Elements and Gold in Ultrabasic Rocks by Inductively Coupled Plasma Mass Spectrometry Using AG-X8 and LN-Resin Sorbents. J. Analyt. Chem. 2020, 75, 769-777. [CrossRef] 
39. Hofmann, A.W. Chemical differentiation of the earth: The relationship between mantle, continental and ocean crust. Earth Planet Sci. Lett. 1988, 90, 297-314. [CrossRef]

40. Distler, V.V.; Kulagov, E.A.; Sluzhenikin, S.F.; Laputina, I.P. Quenched sulfide solid solutions in the ores of the Norilsk 1 deposit. Geol. Ore Depos. 1996, 38, 41-53.

41. Duran, C.J.; Barnes, S.J.; Mansur, E.T.; Dare, S.A.S.; Bedard, P.; Sluzhenikin, S.F. Magnetite Chemistry by LA-ICP-MS Records Sulfide Fractional Crystallization and Sulfide-Silicate/Fluid Interactions in Massive Ni-Cu-PGE Ores from the Norilsk-Talnakh Mining District (Siberia, Russia). Econ. Geol. 2020, 115, 1245-1266. [CrossRef]

42. Naldrett, A.J. Magmatic Sulfide Deposits: Geology, Geochemistry and Exploration; Springer: Heidelberg, Germany, $2004 ;$ p. 727.

43. Radko, V.A. Model of dynamic differentiation of intrusive traps in NW Siberian platform. Russ. Geol. Geophys. 1991, 11, 19-27. (In Russian)

44. Radko, V.A. Facies of Intrusive and Effusive Magmatism in the Norilsk Region; VSEGEI: St. Petersburg, Russia, 2016; p. 226. (In Russian)

45. Naldrett, A.J. A model for the Ni-Cu-PGE ores of the Noril'sk region and its application to other areas of flood basalt. Econ. Geol. 1992, 87, 1945-1962. [CrossRef]

46. Li, C.; Ripley, E.M.; Naldrett, A.J. A new genetic model for the giant Ni-Cu-PGE sulfide deposits associated with the Siberian flood basalts. Econ. Geol. 2009, 104, 291-301. [CrossRef]

47. Yakobchuk, A.S.; Nikishin, A.M. Noril'sk-Talnakh Cu-Ni-PGE deposits: A revised tectonic model. Miner. Depos. 2004, 39, 125-142. [CrossRef]

48. Krivolutskaya, N.A.; Sobolev, A.V.; Snisar, S.G.; Gongalskiy, B.I.; Hauff, B.; Kuzmin, D.V.; Tushentsova, I.N.; Svirskaya, N.M.; Kononkova, N.N.; Schlychkova, T.B. Mineralogy, geochemistry and stratigraphy of the Maslovsky Pt-Cu-Ni sulfide deposit, Noril'sk Region, Russia: Implications for relationship of ore-bearing intrusions and lavas. Miner. Depos. 2012, 47, 69-88. [CrossRef]

49. Krivolutskaya, N.A. Siberian Traps and Pt-Cu-Ni Deposits in the Noril'sk Area; Springer: Cham, Switzerland; Heidelberg, Germany; New York, NY, USA; Dordrecht, The Netherlands; London, UK, 2016; p. 364.

50. Krivolutskaya, N.; Gongalsky, B.; Kedrovskaya, T.; Kubrakova, I.; Tyutyunnik, O.; Chikatueva, V.; Bychkova, Y.; Kovalchuk, E.; Yakushev, A.; Kononkova, N. Geology of the Western Flanks of the Oktyabr'skoe Deposit, Noril'sk District, Russia: Evidence of a Closed Magmatic System. Miner. Depos. 2019, 54, 611-630. [CrossRef]

51. Likhachev, A.P. Platinum-Copper-Nickel and Platinum Deposits; Eslan: Moscow, Russia, 2006; p. 496. (In Russian)

52. Likhachev, A.P. Possibility of mantle magma self-enrichment in ore matter and heavy isotope $34 \mathrm{~S}$ to form platinum-copper-nickel deposits. Perspectives of ore localization in the Norilsk region. Otechestvennaya Geol. 2019, 3, 32-49. (In Russian)

53. Krivolutskaya, N.A.; Plechova, A.A.; Kostitsyn, Y.A.; Belyatskii, B.V.; Roshchina, I.A.; Svirskaya, N.M.; Kononkova, N.N. Geochemical Aspects of the Assimilation of Host Rocks by Basalts during the Formation of Norilsk Cu-Ni Ores. Petrology 2014, 22, 128-150. [CrossRef]

54. Krivolutskaya, N.A. Formation of PGE-Cu-Ni deposits in the process of evolution of flood basalt magmatism in the Noril'sk region. Geol. Ore Depos. 2011, 53, 303-339. [CrossRef]

55. Sluzhenikin, S.F.; Krivolutskaya, N.A.; Rad'ko, V.A.; Malitch, K.N.; Distler, V.V.; Fedorenko, V.A. Ultramafic-mafic intrusions, volcanic rocks and PGE-Cu-Ni sulfide deposits of the Noril'sk Province, Polar Siberia. Yekaterinburg 2014, 83. [CrossRef]

56. Mungall, J.E.; Brenan, J.M.; Gobel, B.; Barnes, S.; Gaillard, F. Transport of metals and sulfure in magmas by flotation of sulfur melt on vapor bubbles. Nat. Geosci. 2015, 8, 216-218. [CrossRef]

57. Yao, Z.; Mungall, J.; Qin, K. A preliminary model for the migration of sulfide droplets in a magmatic conduit and the significance of volatiles. J. Petrol. 2020, 60, 2281-2316. [CrossRef]

58. Portnyagin, M.; Hoernle, K.; Plechov, P.; Mironov, N.; Khubunaya, S. Constraints on mantle melting and composition and nature of slab components in volcanic arcs from volatiles $\left(\mathrm{H}_{2} \mathrm{O}, \mathrm{S}, \mathrm{Cl}, \mathrm{F}\right)$ and trace elements in melt inclusions from the Kamchatka Arc. Earth Planet. Sci. Lett. 2007, 255, 53-69. [CrossRef]

59. Portnyagin, M.V.; Hoernle, K.; Storm, S.; Mironov, N.L.; van den Bogaard, C.; Botcharnikov, R. $\mathrm{H}_{2} \mathrm{O}-$ rich melt inclusions in fayalitic olivine from Hekla volcano: Implications for phase relationships in silicic systems and driving forces of explosive volcanism on Iceland. Earth Planet. Sci. Lett. 2012, 357, 337-346. [CrossRef]

60. Mironov, N.L.; Portnyagin, M.V. $\mathrm{H}_{2} \mathrm{O}$ and $\mathrm{CO}_{2}$ in parental magmas of Kliuchevskoi volcano inferred from study of melt and fluid inclusions in olivine. Russian Geology and Geophysics (special issue Melts and fluids in natural mineral and ore formation processes: Modern studies of fluid and melt inclusions in minerals). Russ. Geol. Geophys. 2011, 52, $1353-1367$.

61. Sobolev, A.V.; Krivolutskaya, N.A.; Kuzmin, D.V. Petrology of primary malts and mantle sources of the Siberian traps province. Petrology 2009, 17, 276-310. [CrossRef]

62. Sobolev, A.V.; Arndt, N.; Krivolutskaya, N.A.; Kuzmin, D.V.; Sobolev, S.V. The Origin of Gases that caused the Permian-Triassic Extinction. In Volcanism and Global Environmental Change; Schmidt, A., Fristad, K.E., Elkins-Tanton, L.T., Eds.; Cambridge University Press: Cambridge, UK, 2015; pp. 147-163. 